\title{
Impact of drill cutting releases on benthic foraminifera at three exploration wells drilled between 1992 and 2012 in the SW Barents Sea, Norway
}

\author{
Noortje Dijkstra $^{a} *$, Juho Junttila ${ }^{a}$, Steffen Aagaard-Sørensen ${ }^{a}$ \\ ${ }^{\mathrm{a}}$ Department of Geosciences, UiT The Arctic University of Norway in Troms $\varnothing$, Postboks 6050 \\ Langnes, N-9037 Troms $\varnothing$, Norway
}

*Corresponding author: noortje.dijkstra@uit.no phone: +47 77623313

email JJ: juho.junttila@uit.no ; email SAS: $\underline{\text { steffen.sorensen@uit.no }}$

\begin{abstract}
The aim of this study is to identify the environmental impact of drill cuttings (DC) released around three wells drilled in 1992, 2000 and 2012 in the SW Barents Sea. Foraminiferal assemblages are studied in cores taken along transects $<250 \mathrm{~m}$ from wells. Well E-1992 shows no impact of DC on foraminifera indicating that low amounts of released DC limit environmental impact. Impact at wells G-2000 and S-2012, is confined to <30m, and attributable to smothering of fauna, resulting in low foraminiferal density. We therefore argue that previous monitoring studies, mainly focusing on samples collected $>250 \mathrm{~m}$ from wellheads, might not capture the full impact of DC. In well G-2000, a recovery layer indicates partial recovery 15 years after DC releases. In well S-2012, no recovery is observed, 3 years after release. Released DC did not result in faunal composition changes.
\end{abstract}

Keywords: drill cuttings, Barents Sea, benthic foraminifera, barium, smothering, environmental monitoring

\section{Declarations of interest: none}

Funding: This work was funded through the Barents Sea Drill Cuttings Research Initiative (BARCUT) - project (WP 3) funded by ENI Norway. RDA Troms County supplied additional support. The funding sources had no involvement in conducting the research and/or preparation of the article. 


\section{Highlights:}

- Environmental impact of drill cuttings around wells in Barents Sea are investigated

- The environmental impact is confined to $<30 \mathrm{~m}$ from the wellhead

- Main impact on foraminifera is attributed to smothering of fauna

- No changes in foraminiferal faunal composition due to drill cuttings are observed

- Partial environmental recovery is observed 15 years after release 


\section{Introduction}

In recent decades, the Barents Sea (Fig.1) has experienced a fast growth in exploration drilling activities, which is expected to continue in the coming years. Opening of new areas for petroleum exploration drilling can result in enhanced environmental pressure on the marine environment, which might result into changes in sediment quality and ecosystem structure (e.g. Aagaard-Sørensen et al., 2018; Breuer et al., 2004; Davies et al., 1984; Jorissen et al., 2009; Junttila et al., 2018). Changes in ecosystem structure will affect the types of organisms dominating the marine environment, which in turn can affect the potential for marine bio-resources (e.g. fishing industry). In-depth knowledge on the long-term environmental effect of exploration drilling in the Arctic region is therefore of great relevance.

One particular concern in exploration drilling are drill cuttings, which are discharged to the sea floor environment during the drilling process. Drill cuttings is a general term used to describe the mixture of drilling mud (fluids and solids), rock fragments, sediments, and specialty chemicals including heavy metals and PAHs (Breuer et al., 2004). Drill cutting release is nowadays subjected to strict requirements, especially in the Barents Sea area (Knol, 2011). The release of oil based drill cuttings, containing high amounts of toxic chemicals (Knol, 2011), was allowed during the 1980's until the ban on release of oil based drill cuttings in 1993 (NPD, 2017). The release of oil based drill cuttings has resulted in high concentrations of heavy metals and PAHs into the marine environment (Breuer et al., 2004; Davies et al., 1984). In 1997, the Norwegian government set a goal of zero discharge of oil and environmentally hazardous substances for the entire Norwegian Continental Shelf (White Paper No.58; Ministry of Environment 1997). Stricter requirements were set in 2003 for the northern part of the Norwegian Continental Shelf, i.e. the Barents Sea and Lofoten region. According to these regulations, only drill cuttings from the top hole can be released when no hazardous substances are used in areas unlikely to experience environmental damage (Storting White paper No.38; Ministry of Petroleum and Energy 2004). These regulations were moderated in 2011 to zero discharge of hazardous substances (Storting White Paper No.10; Ministry of Environment 2011).

In this study, we investigate the environmental impact of released drill cuttings around three wells in the SW Barents Sea. These three wells were drilled in 1992, 2000 and 2012. The wells were thus drilled under different discharge regulations, i.e. before ban on oil-based drill cuttings (well from 1992), after ban on oil-based drill cuttings (well from 2000), zero- 
discharge of hazardous substances (well from 2012). Sediment cores were collected at each well along downstream transects, at ca.5, 30, 60, 125 and $250 \mathrm{~m}$ from the well (see chapter 3.1 Sample collection). This is in closer proximity than traditional monitoring studies in the Barents Sea, where samples mainly have been collected $>250 \mathrm{~m}$ from the wellhead (Renaud et al., 2008).

The environmental impact of drill cuttings is investigated by changes in foraminiferal fauna composition around the wells. Benthic foraminifera are unicellular organisms (size: 45-1000 $\mu \mathrm{m})$ living in the upper layers of the seafloor (Murray, 2006). Foraminifera are widely used as indicators for climatic and environmental changes. They are considered ideal for (bio)monitoring purposes, as they have a high sensitivity to environmental change. They respond quickly to both natural and anthropogenic alterations due to their short reproductive cycle (Murray, 2006). An advantage of benthic foraminifera is that their shells fossilize in the sedimentary record. By studying living and fossilized foraminiferal assemblages in sediment cores, it is possible to go back in time and reconstruct past environmental conditions. This includes environmental impact of contaminants (Aagaard-Sørensen et al., 2018; Dijkstra et al., 2017b; Hess et al., 2013), reconstruction of environmental baselines in already impacted areas (Dijkstra et al., 2017a; Dolven et al., 2013), and monitoring of ecosystem recovery after environmental pressure has diminished (e.g. Aagaard-Sørensen et al., 2018; Berg, 2017; Polovodova Asteman et al., 2015).

Previous studies showed that the main effect of drill cuttings on foraminifera is smothering by drill cutting material, resulting in a rapid drop in foraminiferal density (e.g. Aagaard-Sørensen et al., in review; Aagaard-Sørensen et al., 2018; Berg, 2017; Hess et al., 2013). Elevated sediment heavy metal concentrations are another factor that might influence foraminiferal faunal composition (e.g. Berg, 2017; Dijkstra et al., 2017b; Jorissen et al., 2009).

\section{Study area}

The Barents Sea is a shallow shelf sea with maximum water depths around $450 \mathrm{~m}$. The studied wells are all located within the glacially eroded Ingøydjupet trough (300-400 meters below sea level (m.b.s.l)). The study area is surrounded by the shallow banks Tromsøflaket and Nordkappbanken (200-300 m.b.s.l), and the deeper Bjørnøyrenna trough (300-450 m.b.s.l.) (Fig. 1). Ingøydjupet is known to be an area for accumulation of sediments (Jensen et al., 2009; Junttila et al., 2014).

Two main water masses prevail in the study area: Atlantic water and Coastal water (Fig. 1). Coastal water $\left(>2^{\circ} \mathrm{C},<34.7\right.$ psu ) (Loeng, 1991) is transported northwards along the 
Norwegian coast by a shallow surface current. Atlantic water is characterized by higher salinities and temperatures $\left(>3{ }^{\circ} \mathrm{C}\right.$; >35 psu) (Loeng, 1991). Atlantic water follows the Norwegian continental shelf and enters the Barents Sea around Bjørnøyrenna. From there it reaches Tromsøflaket and Ingøydjupet due to the prevailing SW winds (Ingvaldsen et al., 2004).

\subsection{Facts on studied wells}

Three wells are studied. A summary related to the drilling activity is given below. Information was gathered from the Norwegian Petroleum Directorate Fact Pages (NPD, 2017).

- Well E-1992 (7122/4-1). Drilling operator: Esso Exploration and Production Norway A/S. The exploration well was drilled between 13th of November 1991 and 13th of January 1992 to $3015 \mathrm{~m}$ in the Snadd formation of the Late Triassic. Water based drill fluid with (bentonite) gel and $\mathrm{KCl}$ polymer was used.

- Well G-2000 (7122/7-1). Drilling operator: Norsk Agip AS. The exploration well was drilled between $16^{\text {th }}$ of September and $5^{\text {th }}$ of October 2000 to $1524 \mathrm{~m}$ depth in the Tubåen formation of the Early Jurassic. Water based drill fluid, with bentonite, XC polymer and PAC was used.

- Well S-2012 (7220/10-1). Drilling operator: Eni Norway AS. The exploration well was drilled between 13th of August and 16th of October 2012 to 2405 m depth in the Snadd formation of the Late Triassic. Water based drilling fluid was used.

\section{Material and Methods}

\subsection{Sample collection}

In September 2015, $50 \mathrm{~cm}$ long push cores (PC) with a diameter of $8 \mathrm{~cm}$ were retrieved with a remotely operated underwater vehicle (ROV) on board the supply vessel AHTS Njord Viking. The PCs were collected along a downstream transect at distances of 5m (well E-1992), 8m (well S-2012) or $10 \mathrm{~m}$ (well G-2000) from the wellhead. In addition, cores were collected at 30, 60, 125 and $250 \mathrm{~m}$ from the wellhead (Fig. 1, Table 1). All cores were retrieved at ca. 350 $\mathrm{m}$ water depth. At each station, two cores (core A and B) were obtained within half a meter from each other (Table 1). The cores from well E-1992 and S-2012 were subsampled and immediately at a $1 \mathrm{~cm}$ resolution down to $20 \mathrm{~cm}$ core depth, and subsequently frozen. Cores from well G-2000 were frozen completely immediately after retrieval. They were defrosted and subsampled at the UiT laboratories in 2017. Samples of core A were analysed for foraminiferal assemblages (see 3.2), in addition to grain size distribution. Samples of core B 
were analysed for heavy metal content and total organic carbon content. Physical parameters of well E-1992 and S-2012 were previously published in Junttila et al., (2018).

Drill cutting impacted sediments are identified based on elevated Ba concentrations compared to the baseline concentration of the area (ca. $>200 \mathrm{mg} / \mathrm{kg}$ ), following the approach described in Junttila et al., (2018). Based on these identified drill cutting influenced sediment intervals samples were selected for foraminiferal assemblage analyses (Table 1). The cores collected closest to the well were analyzed completely on a $1 \mathrm{~cm}$ interval. For the other stations $(30,60$, 125 and 250) samples were analyzed on a $1 \mathrm{~cm}$ interval until $1 \mathrm{~cm}$ under the deepest drill cutting influenced layer. Samples from below this depth were considered to represent the environmental baseline and were analyzed on a lower resolution (see Table 1).

\subsection{Physical parameters}

Physical parameters from Well E-1992 and S-2012 were previously published in Junttila et al., 2018. Analyses of physical parameters of the cores collected at Well G-2000 were analysed at the same time and with the same methods as those for Well E-1992 and S-2012. The used methodology is summarized below.

Grain size distribution was determined using a Beckman Coulter LS 13320 laser particle size analyzer according to the method described by $\mathrm{Xu}$ (2000). Before using the laser particle analyzer chemical treatment of the samples was performed to remove carbonates and organic material following Dijkstra et al. (2017b).

Total organic carbon (TOC) content was determined using a Leco CS744 induction furnace. Inorganic carbon was removed from the bulk sediment sample prior to measurement.

Heavy metal analyses were performed following EPA methods 200.7 and 200.8 at the certified laboratory Unilab AS, Troms $\emptyset$. The sediments were analyzed for content of Barium (Ba), Mercury (Hg), Cadmium (Cd), Chromium (Cr), Copper (Cu), Lead (Pb), Zinc (Zn) and Titanium (Ti) using inductively coupled plasma atomic emission spectroscopy (ICP-AES) or inductively coupled plasma sector field spectroscopy (ICP-SFMS), depending on the concentrations of the metals following Mannvik et al., (2011). Concentrations of Mercury (Hg) were measured with atom fluorescence (AFS) following Mannvik et al., (2011).

\subsection{Sample treatment for foraminiferal assemblage analyses}

Live foraminiferal assemblages were studied in the top $5 \mathrm{~cm}$ of the sediment cores. Samples intended for live foraminiferal assemblages were thawed in a rose Bengal ethanol mixture (1 $\mathrm{g} / \mathrm{L}$ ethanol $95 \%$ ), to stain preserved cytoplasm. The samples were placed back in a cooling 
room $\left(<5^{\circ} \mathrm{C}\right)$ and staining of the samples was allowed for a minimum of two weeks (Lutze and Altenbach, 1991).

Rose Bengal adsorbs to protein in live and/or not yet decomposed cytoplasm. Due to practical reasons staining of the samples had to be done after sediment samples were frozen during the thawing process (following Aagaard-Sørensen et al., 2018). This is done with the assumption that the protein of cytoplasm stays preserved by freezing of the sediment samples. The absolute abundance of live foraminifera in the samples should however be interpreted with care, in case the cytoplasm was not fully preserved. However, as all samples were frozen before staining, all cores would have experienced a similar loss and relative comparisons can be made between the number of live fauna in impacted and non-impacted samples.

The other samples $(5-20 \mathrm{~cm}$ core depth) were freeze-dried before they were washed over meshes with widths of $1 \mathrm{~mm}, 100 \mu \mathrm{m}$ and $63 \mu \mathrm{m}$.

\subsection{Foraminiferal analyses}

Dead and live faunas were studied in the $100 \mu \mathrm{m}$ to $1 \mathrm{~mm}$ fraction to enable comparison to previous studies from the area (Aagaard-Sørensen et al., 2018; Dijkstra et al., 2017a; Dijkstra et al., 2013; Dijkstra et al., 2015).

For the live fauna, only specimens with a bright stain inside more than half of the chambers were considered to be living at the time of sampling (de Stigter et al., 1998; de Stigter et al., 1999). We aimed to identify a minimum of 300 specimens per sample (Schönfeld et al., 2012). However, due to low foraminiferal density in some samples this number was not always reached, especially not for the live assemblages. Statistical studies based on a large number of paleo-ecological datasets, demonstrated that a sample size ranging between 25 and 60 specimens effectively produced the same multivariate result as samples based on a larger amount of specimens (Forcino, 2012; Forcino et al., 2015).

Foraminifera were identified following the generic classification of Loeblich and Tappan (1987) and the holotype descriptions in the Ellis and Messina catalogues (Ellis and Messina, 1940-1978). Nomenclature follows largely the accepted species names published in the WoRMS database (Mees et al., 2015). Some species were grouped during identification, see Supplementary data A for species lists and taxonomic notes.

Dead foraminiferal data is presented throughout the article as both relative abundance (\%) and absolute abundances (\# specimens/g bulk dry sediment) (hereafter referred to as \#/g). The well-known (Dijkstra et al., 2015; Murray, 2006 and references therein) poor down core preservation of agglutinated taxa requires consideration when calculating foraminiferal 
abundance (Harloff and Mackensen, 1997; Mackensen et al., 1990). Hence, abundances of agglutinated and calcareous taxa have been calculated separately based on the total number of agglutinated and calcareous specimens per sample respectively. Live fauna is presented as total live fauna, including benthic and agglutinated species, as preservation is not an issue.

Foraminiferal density is defined as the calcareous total absolute abundance of a sample, i.e. the number of calcareous specimens observed in a sample standardized to gram dry bulk sediment.

Diversity is expressed by the Fisher alpha and dominance (D) indices. These indices were calculated using statistical software PAST version 3.06c (Hammer et al., 2001).

Statistical analyses were performed using the statistical program PAST version 3.06c (Hammer et al., 2001). The data was standardized before analyses by log-transformation $(\log (1+\mathrm{X}))$ to remove the effect of different orders of magnitudes.

Foraminiferal species were grouped with R-mode hierarchical clustering, using Ward's method and Euclidean distance (Ward, 1963), to identify different associations. Absolute abundance, standardized to \#/g, was used as input for R-mode clustering. Only species that had a relative abundance of $>5 \%$ in at least one sample were considered (Fishbein and Patterson, 1993). Based on the R-mode clustering two associations could be defined (see Results). The summed abundance of these two associations was used as input for Q-mode hierarchical clustering, using Ward's method and Euclidian distance, to find similarity between the samples of each well. Additionally, non-metric multidimensional scaling (NMDS), with Euclidian distance as similarity measure, was performed using the same input to visualize the level of similarity of the samples within each well, following the algorithm of Taguchi and Oono (2005). Environmental parameters were added to this analysis, however not included to the ordination. Ba, fine fractions $(<63 \mu \mathrm{m})$ and TOC were used as environmental parameters, with $\mathrm{Ba}$ acting as an indicator of sediments influenced by drill cuttings (Junttila et al., 2018). Fine fraction and TOC were included as natural parameters influencing the foraminiferal assemblage (Dijkstra et al., 2013). For well S-2012, Cu was additionally added as environmental parameter, as the metal data showed that Cu levels in S8 were of levels considered to be of levels harmful to the environment (Table2; See discussion in Results and Discussion).

\section{Results}

\subsection{Live foraminiferal fauna}


In general, the live foraminiferal density decreases with depth. Below results are described as the summed abundance of the taxa in the entire top $5 \mathrm{~cm}$ of the core (Fig.2).

At well E-1992, the foraminiferal density varies between 3.6 \#/g (station 30) and 11.6 \#/g (station 125). Calcareous specimens are more abundant than agglutinated specimens (Fig 2a) are. The number of species varies between 16 (station $5 \& 60$ ) and 22 (station 125) and shows a similar trend as the Fisher alpha diversity (2.4-4). Dominance varies between 0.13 (station 60/250) and 0.26 (station 5) (Fig.2b).

At well G-2000, the foraminiferal density varies between 1.4 \#/g (station 60/250) and $4.3 \mathrm{\# /g}$ (station 125). Calcareous specimens are more abundant than agglutinated specimens (Fig 2a) are, with the exception of station G60. The number of species varies between 8 (station 60) and 25 (station 5). A similar trend is observed for the Fisher alpha diversity (1.2-4.6). Dominance varies between 0.09 (station 5) and 0.3 and is highest in station G60 (Fig.2b).

At well S-2012, the foraminiferal density varies between 0 \#/g (station 5) and 10.2 \#/g (station 125). The foraminiferal density in station $\mathrm{S} 125$, is much higher than in the other stations. Calcareous specimens are more abundant than agglutinated specimens (Fig 2a) are. The number of species varies between 6 and 19 (station 250), with a relatively lower amounts of taxa in station S5 and S125. Dominance varies between 0.1 (station 5) and 0.28 and is highest in station S125 (Fig.2b).

Main species (Fig. 2c) present in the live assemblages (> 10\% in at least one station) at the three wells include: Reophax spp., Trochammina spp., Cassidulina laevigata, Cibicides lobatulus, Epistominella nipponica, Melonis barleeanus, Pullenia bulloides and Trifarina angulosa (Supplementary data A). Additionally, at well S-2012 >10\% abundance of Haplophragmoides spp. (station S30), Islandiella spp. (station S5), Millioninella spp. (station S30), Pyrgo subglobusum (station S5) and Rosalina spp. (station S5) are found. It should be noted that these high relative abundances of the latter species coincides with low amounts of living foraminifera.

\subsection{Dead foraminiferal fauna}

Overall, the dead foraminiferal density (\#/g) decreases with depth (Fig. 3b, 4b, 5b), this is a natural phenomenon observed within the SW Barents Sea (Dijkstra et al., 2017a). Agglutinated fauna naturally decreases down core in abundance due to the poor preservation of agglutinated species over time and are therefore not included in the results below.

Main species (Fig. 3c, 4c, 5c) present in the dead assemblages (>10\% in at least one station) at the three wells include: Cassidulina neoteretis, Cassidulina reniforme, Elphidium 
clavatum, Islandiella spp., Nonionellina labradorica, C. laevigata, C. lobatulus, E. nipponica, M. barleeanus, P. bulloides and T. angulosa. Islandiella spp. consists mainly of the summed abundance of Islandiella norcorssi and Islandiella helenae (Supplementary data A).

Additionally, other species reach abundances $>10 \%$, i.e. Buccella spp. (G10), Elphidium albiumbilicatum (G10), Bulimina marginata (S8), Fissurina spp. (S30), Milliolinella spp. (S8) and Quinqueloculina seminulum (S8). However, this is only the case when <100 specimens were identified.

We will not describe the down core changes in the foraminiferal assemblage outside the drill cutting influenced layers in detail, as they attributable to natural environmental change and hence outside the scope of this paper.

\section{$\underline{4.2 .1 \text { Well E-1992 }}$}

Absolute calcareous abundances (\#/g) are highest in the top of the cores in each of the stations (128-480 \#/g). Relatively lowest abundances are observed in E30 and E250, and highest in E60. In all cores but E60, intervals of less than 10 specimens per gram are observed, i.e. 7-17 $\mathrm{cm}$ (E5), 6-14 cm (E30), 13-20 cm (E125) and 7-17 cm (E250), of which the corresponding interval of E5 is barren for foraminifera (Fig.3b).

Dominance and diversity are varying between 0 (E5) and 0.37 (E30), and 0 (E5) and 5.72 (E250) respectively. Dominance is slightly higher in E30 (average 0.21) and E125 (0.18), compared to the other stations with average dominance varying between 0.14 and 0.16 . Diversity is slightly higher in station E125 (average 4.33), compared to the other stations with average dominance varying between 2.72 and 3.93 (Fig.3c).

Overall, C. laevigata, C. lobatulus, E. nipponica, M. barleeanus, P. bulloides and T. angulosa dominate the assemblages at this well, both in relative and absolute abundances. In core E5 and E125, C. reniforme, E. clavatum, Islandiella spp., and N. labradorica have higher relative abundances in the bottom part of the cores (Fig.3d).

\subsubsection{Well G-2000}

Absolute calcareous abundances (\#/g) are highest in the top of the cores from station G10, G30 and G125, whereas in station G60 and G250 values fluctuate around 130 and 115 \#/g respectively. Overall abundances vary between 0.6 and $237 \# / g$. Absolute abundances are lowest in the $8-20 \mathrm{~cm}$ interval of core G10, with abundance below $10 \# / \mathrm{g}$. Above $8 \mathrm{~cm}$ core depth, abundances are gradually increasing, up to values above $100 \# / \mathrm{g}$ in the $0-4 \mathrm{~cm}$ core 
depth interval. In core G125 abundances $<10 \# / g$ are observed between 11 and $14 \mathrm{~cm}$ core depth (Fig.4b).

Dominance and diversity are varying between 0.10 (G10) and 0.47 (G30), and 1.26 (G10) and 8.25 (G10) respectively. Dominance is highest in G10 (average 0.22), compared to the other stations with average dominance varying between 0.16 and 0.17 . Higher dominance $(>0.2)$ coincides with intervals of low calcareous absolute abundance described above for core G10 and G125. Diversity is slightly higher in station G10 (average 4.17) and G.30 (4.04), compared to the other stations with average dominance varying between 3.76-3.78. A diversity of $>6$ is only observed in the interval of relatively high absolute abundances $(0-4$ $\mathrm{cm}$ ) in core G10 (Fig.4c).

For the cores G30-G250, C. laevigata, C. lobatulus, E. nipponica, M. barleeanus, P. bulloides and $T$. angulosa dominate the assemblages, both in relative and absolute abundances. In core G10, these species dominate as well in the top of the core, corresponding to the interval of high absolute abundances and diversity $(0-4 \mathrm{~cm})$. In the lower core intervals relative abundances of $C$. reniforme, E. clavatum, Islandiella spp., and N. labradorica, in addition to C. lobatulus are dominating. It should however be noted that foraminiferal density is low in these interval and relative abundance are not reliable. Additionally, in G10 intervals of foraminifera that looked weathered and polished are observed below $4 \mathrm{~cm}$ core depth. (Fig.4d)

\subsubsection{Well S-2012}

In cores S30-250, absolute calcareous abundances (\#/g) are highest in the top of the cores (22$851 \mathrm{\# /g}$ ). In core $\mathrm{S} 8$, relative abundances are very low, with values fluctuating between 0 and $0.55 \# / g$, with an average of $0.08 \# / g$. In all cores but S250, intervals with no or $<2 \# / g$ are observed, i.e. 0-20cm (S8), 12-15 cm (S30), 6-12 cm (S60) and 7-16 cm (S125) (Fig.5b).

Dominance is varying between 0 and 1 in S8 (average 0.24), and between 0 and 0.3 in the other stations (S30-S250). Of these latter stations, dominance is slightly higher in S250 (average 0.18), compared to the other stations with average dominance varying between 0.11 and 0.14. Diversity in stations S8 varies between 3.71 and 43.45 . The latter high diversity is observed in the $4-5 \mathrm{~cm}$ interval and only 10 individuals were identified, belonging to 9 different taxa. In station S30, diversity varies between 0 and 15.43. The latter high diversity is observed in the 14-15 cm interval and only 31 individuals were identified, belonging to 17 different taxa. In the other stations diversity varies between 0 and 6.51. Of these latter 
stations, diversity is slightly higher in station S250 (average 3.93), compared to the other stations with average dominance varying between 2.19-2.78 (Fig.5c).

Overall, C. laevigata, C. lobatulus, E. nipponica, M. barleeanus, P. bulloides and T. angulosa dominate the assemblages, both in relative and absolute abundances in cores S30-250. In core S30 and S60, C. reniforme, E. clavatum, Islandiella spp., and N. labradorica have higher relative abundances in the bottom part of the cores. The relative abundances of the few specimens that are observed in core S8 are considered not to give realistic relative abundances (Fig.5d).

\subsection{Physical parameters}

Results of the grain size distributions, heavy metal content and total organic carbon content of well S-2012 and E-1992 are described and discussed in Junttila et al., (2018) (Fig. 3E and 5E). The results for the same parameters of well G-2000 are briefly summarized below.

Silt $(2-63 \mu \mathrm{m})$ is the dominating grainsize class in all stations of well G-2000 (average silt content 55-65 \%), apart from at station G250 (average silt content 43\%). In station G250, clay $(0-2 \mu \mathrm{m})$ is the main grain size class (average clay content $48 \%$ ), while in the other stations, the average clay content varies between 9-13\%. Average sand content varies between 9 (G250) and $34 \%$ (G30 \& G125) (Fig. 4E). The TOC content of the cores varies between 0.07-0.4 (G10), 0.2-0.5 (G30), 0.3-0.4 (G60), 0.2-0.3 (G125 \& G250) (Fig. 4E). The range in concentrations of heavy metals and Ba (Fig. 4A) in well G-2000 is shown in Table 2 and Supplementary data B.

Visual observations during micropaleontological analyses with a microscope show that the sediment grains in the lower part $(4-20 \mathrm{~cm})$ consist of a large number of foam like particles and green particles (Supplementary figure Ia), while in the other cores at the transect (G30G250) these type of particles are absent. Sediment from the top $4 \mathrm{~cm}$ of core G10 also have low amounts of these particles (Supplementary figure Ia).

\subsection{Statistics}

R-mode clustering divided the species into two associations (Fig. 6a). Association I consists of M. barleeanus, P. bulloides, T. angulosa, C. lobatulus, C. laevigata and E. nipponica. Association II consists of E. albiumbilicatum, N. labradorica, Islandiella spp., Oolina spp., E. clavatum, Lagena spp., C. neoteretis and C. reniforme. The ratio between association I and II is plotted in Fig. 6b. 
Q-mode clustering based on the summed absolute abundance of association I and II was performed for each of the wells. The Q-mode clustering divides the samples into two groups (Suppl. Fig. II). In general, samples clustered in group I correspond to samples with relatively high amounts of species from association I, while samples clustered in group II correspond to samples with relatively high amounts of species from association II. For Well G-2000 and S2012, the NMDS-plot gives clear clusters of samples, while for well E-1992 the analysis gives a more scattered pattern. The biplot shows the correlation coefficients between each environmental parameter and the NMDS scores. For Well E-1992, the sample scores scatter around the biplot. For Well G-2000, samples of group I plot in the same direction as TOC, while samples of group II plot towards fine fraction and Ba. In well S-2012, the NMDS scores of group II plot towards $\mathrm{Cu}$ and $\mathrm{Ba}$, while samples of group I plot partly around fine fraction and TOC.

\section{Discussion}

\subsection{Drill cutting influenced sediment layers}

Samples presented in this paper were collected in 2015. The seafloor environment thus had ca. 23 years (Well E-1992), 15 years (Well G-2000) or 3 years (Well S-2012) to recover from potential environmental impact of the released drill cuttings.

At well E-1992, drill cutting influenced layers were 4 to $5 \mathrm{~cm}$ thick in core E5 and E30 respectively. A $6 \mathrm{~cm}$ thick layer was observed in core E60, E125 and E250 (Fig. 3a; Supplementary figure III) (Junttila et al., 2018). At well G-2000, the entire core G10 shows sediments impacted by drill cuttings. In cores G30, G60, G125 and G250 drill cutting impacted sediments are confined to the upper 4, 2, 2 and $4 \mathrm{~cm}$ respectively (Fig.4a). At well S-2012, the entire S8 shows sediments impacted by drill cuttings. In cores S30, S60, S125 and S250 drill cutting impacted sediments are confined to the upper 4, 2, 2 and $1 \mathrm{~cm}$ respectively (Fig.5; Junttila et al., 2018). It should be emphasized that $\mathrm{Ba}$ is considered to be non-toxic (Neff, 2005). Several laboratory and field studies have shown that the metals associated with barite in drilling mud or cuttings piles generally have a low bioavailability to marine animals and do not accumulate in the tissues of bottom-living animals (Neff, 2005).

Copper values in station S8 (0-16 cm core depth) are of concentrations considered to be within environmental quality class IV (bad) (Bakke et al., 2010). This corresponds to values considered to be harmful for the environment. Cadmium values in the top sample $(0.5 \mathrm{~cm})$ of station S8 are considered to be of environmental quality class III (moderate). All metal concentrations in all other stations are considered to be of levels not harmful to the 
environment (class I). It is therefore unlikely that they have an impact on the foraminiferal assemblage.

\subsection{Environmental conditions and natural environmental change}

Environmental preferences of benthic foraminifera and references to literature are summarized in Table 3. Cluster analyses divide the foraminiferal species into two associations. Association I includes the species M. barleeanus, $P$. bulloides, C. laevigata and E. nipponica. These are mainly of species associated to warm Atlantic or nutrient rich conditions (e.g. Altenbach et al., 1999; Hald and Steinsund, 1992; Jennings et al., 2004; Mackensen and Hald, 1988; Saher et al., 2012; Sejrup et al., 2004; Steinsund, 1994). Additionally $T$. angulosa and C. lobatulus indicative for sandy sediment conditions and relatively higher energy environment are grouped in Association I (e.g. Hald and Steinsund, 1996; Mackensen et al., 1985; Nyholm, 1961; Steinsund, 1994). The species grouped in Association I are species typically found in the present day natural settings of Ingøydjupet (Dijkstra et al., 2015) and the southern part of Bjørnøyrenna (Dijkstra et al., 2017a).

Association II consists of species $N$. labradorica, Islandiella spp., E. clavatum and $C$. reniforme These are species associated to relatively colder Arctic conditions (e.g. Hald and Korsun, 1997; Hald and Steinsund, 1992; Korsun and Hald, 1998; Polyak and Solheim, 1994; Sejrup et al., 2004; Smart and Gooday, 1997; Sun et al., 2006; Wilson et al., 2011). Species of Association II are typically found in the more northern parts of Bjørnøyrenna and the Barents Sea (Dijkstra et al., 2017a). E. clavatum and C. reniforme, are species that are additionally associated to stressed environments, either natural anthropogenic (Alve, 1995; Hald and Korsun, 1997). These two species have been reported as one of the first species to recolonize former barren areas when environmental pressure is reduced (Schafer et al., 1991) and are known to be capable of adapting to harsh environments (e.g. Alve, 1999; Corliss, 1985; Corliss and Van Weering, 1993; Linke and Lutze, 1993; Wollenburg and Mackensen, 1998). Overall, it can be concluded that species grouped in Association I indicate relatively warm, food rich Atlantic conditions, found in the present-day southern part of the SW Barents Sea. Species grouped in Association II indicate relatively cooler and fresher Arctic-like conditions, found in the present-day northern part of the SW Barents Sea. In addition, some of the species grouped in Association II have opportunistic characteristics. Presence of these species could therefore potentially also be related to harsh conditions during and after drill cutting releases. 
All cores collected at well E-1992, core G30 and G125 and cores S30 to S250, show increased foraminiferal densities in the top part of the cores (Fig.3b-5b). This coincides with elevated Ba concentrations (Fig.3-5a). This might give the impression that elevated $\mathrm{Ba}$ concentrations positively influence foraminiferal abundances. However, increasing densities towards present day (i.e. core top) is a well-known phenomenon in the SW Barents Sea (e.g. Dijkstra et al., 2017; Dijkstra et al., 2015). It can be attributed to enhanced inflow of Atlantic water towards the area creating more favourable conditions for benthic foraminifera and hence higher foraminiferal densities. Enhanced inflow of Atlantic water is additionally supported by higher relative and absolute abundances of species associated with Atlantic conditions, i.e. C. laevigata, E. nipponica, M. barleeanus and P. bulloides (Fig.3-5d). Enhanced inflow of Atlantic water into the Barents Sea since 1980 CE is a well-documented phenomena (Bengtsson et al., 2004; Ingvaldsen et al., 2002).

Down core changes in fossil foraminiferal faunal composition outside drill cutting influenced sediment layers are interpreted to be attributable to natural environmental and climatic changes.

In cores E5-E125 a shift from relatively high abundances (\% and \#/g) of cool associated species C. reniforme, E. clavatum, Islandiella spp. and $N$. labradorica (grouped in Association II) to higher abundances (\% and \#/g) of C. laevigata, C. lobatulus, E. nipponica, M. barleeanus, P. bulloides and T. angulosa is observed (Fig. 3b). A similar shift is observed in cores S30-S125 (Fig. 5). Similar higher abundances of cool associated species followed by a shift to Atlantic water associated assemblages, are observed in cores studied in Ingøydjupet (Dijkstra et al., 2015) and southern part of Bjørnøyrenna (Dijkstra et al., 2017a). These shifts are attributed to the shift from the cool Little Ice Age (LIA) towards the period of Modern Warming (MW) (Lamb, 1977). A more detailed discussion of these natural environmental changes is beyond the scope of this paper.

\subsection{Environmental impact of drill cuttings}

One well documented effect of released drill cuttings is smothering of in-situ fauna (e.g. Aagaard-Sørensen et al., 2018; Cochrane et al., 2019; Dijkstra et al., 2015; Hess et al., 2013). Smothering can result in low foraminiferal densities or barren sediment intervals. Experimental studies showed a smothering effect on foraminifera when the drill cutting layer exceeds $2.4 \mathrm{~cm}$ (Hess et al., 2013). Observations of smothering were made in wells located in our study area (Well G-2006 and Well T-1987; Fig. 1b) (Aagaard-Sørensen et al., 2018) when the drill cutting layer is thicker than $3 \mathrm{~cm}$. 
Low foraminiferal densities in the lower part of core G10, coinciding with high Ba concentrations. $\mathrm{Ba}$ is considered to be non-toxic and other metal concentrations were not elevated within these Ba-rich layers. This suggests that the low foraminiferal densities most likely reflect smothering of the in-situ fauna. In addition, the low foraminiferal densities in core S8 suggest that the $>20 \mathrm{~cm}$ drill cutting deposited close to well S-2012 smothered the insitu fauna.

All cores collected at well E-1992, cores G30-G250 and core S30 show drill cutting influenced sediment layers of $>3 \mathrm{~cm}$ in thickness (Fig.3-5). Rapid deposition of such thick layers of drill cuttings would be expected to smother the foraminiferal fauna (Hess et al., 2013). However, within these layers lower foraminiferal densities are not observed. We argue that this indicates that the initial deposited drill cutting layer was not thick enough (i.e. less than $3 \mathrm{~cm}$ ) to smother the foraminiferal fauna. The prevailing fauna was maintained at the coring sites and could bioturbate through the deposited drill-cutting layer. The $>3 \mathrm{~cm}$ thick drill cutting influenced sediments are therefore more likely the result of gradual retransportation of Ba-rich sediments from the original drill cutting deposit at the well towards the core locations. Similar observation of re-transportation of drill cuttings were made at a well located in our study area drilled in 1987 (Well T-1987; Fig. 1b) (Aagaard-Sørensen et al., in review; Berg, 2017). Gradual re-transportation of Ba-rich sediments towards the core locations is supported by increased Ba values towards the top of the cores (Junttila et al., 2018).

It should be noted that other intervals barren for foraminifera or with low foraminiferal densities were observed in cores E5, G30-G125 and S30-S125 (Fig. 3-5). These barren intervals do not coincide with drill cutting influenced sediments, nor high concentrations of other heavy metals (Junttila et al., 2018 and Table 2/ Supplementary data B). We therefor interpret these intervals to have a natural cause. A more detailed discussion of what this natural cause might be is beyond the scope of this paper.

Changes in dominating foraminiferal taxa is another potential impact of released drill cuttings and their associated contaminants (Aagaard-Sørensen et al., in review; Aagaard-Sørensen et al., 2018; Berg, 2017; Jorissen et al., 2009; Mojtahid et al., 2006). In our study we only observed a faunal changes that coincides with Ba enriched layers in one core, i.e. core G10. Other faunal changes observed in the cores were outside drill cutting influenced layers and could be attributed to natural causes as briefly discussed above (chapter 5.2). 
Based on the dead foraminiferal assemblages, core G10 can be divided into two parts. The lower part (4-20 cm) of the core is characterized by low densities (\#/g; Fig. 4b), while the top of the core (0-4 cm core depth) show higher densities. This shift in foraminiferal density is accompanied by a shift from high relative abundances of C. reniforme, E. clavatum, Islandiella spp., N. labradorica and $C$. neoteretis to higher relative abundances of $C$. laevigata, E. nipponica, M. barleeanus, P. bulloides and T. angulosa (Fig. 4d). This indicates that at $4 \mathrm{~cm}$ core depth we observed a shift from species associated with cooler Arctic conditions towards species associated to the warmer Atlantic conditions (Dijkstra et al., 2017a; Dijkstra et al., 2013; Dijkstra et al., 2015; Saher et al., 2012; Sejrup et al., 2004). It should be noted that foraminiferal abundances are low (specimens identified per sample $<100)$, hence relative abundances should be interpreted with care.

As the entire core G10 is interpreted to consist of drill cutting impacted layers, the sediments captured at the coring site must all have been deposited during or after the release of drill cuttings at the well in September/October 2000. The cold and harsh, polar like environmental conditions, as suggested by the foraminiferal assemblage, did not prevail in Ingøydjupet during this time period (Dijkstra et al., 2015). E. clavatum and C. reniforme are species that are additionally associated to stressed environments, either by natural or anthropogenic induced stressful conditions (Alve, 1995; Hald and Korsun, 1997). The presence of these species could therefore be related to the release of drill cuttings to the area. However, drill activities at well G-2000 lasted over the span of ca. only 15 days (NPD, 2017). It is unlikely that these species populated the area within this short of a time span. It is therefore more likely that the impacted foraminiferal fauna was released together with the drill cuttings. This is supported by observations of damaged and polished foraminifera in this interval of the core. Similar observations were previously made at a well at the same petroleum field (AagaardSørensen et al., 2018; Well G-2006; Fig.1b). Low densities in addition to significant higher abundances of species of Association II are not observed in the Ba-enriched layers of core G30-G250.

R-mode clustering and NMDS (Suppl. Figure II) confirms the presence of two associations down core within the foraminiferal assemblage and their potential environmental interpretation. R-mode clustering grouped all samples from the lower part of G10 together in group II, while most of the samples from the other cores were grouped together with samples from the top $4 \mathrm{~cm}$ of core G10 in group I (Fig.6b and Suppl. Figure II). This is confirmed by the biplot of the NMDS, in which the group II cluster plots towards the same direction as $\mathrm{Ba}$, indicative of drill cutting rich sediments. Additionally, samples with low foraminiferal 
abundances from cores G30 and G125 are grouped in group II. These samples are however from intervals not impacted by drill cuttings. We therefore argue that, for well G-2000, samples of group II reflects challenging conditions, either anthropogenic (samples of G10) or natural (samples of G30 and G125).

Overall it can be concluded that the environmental impact of the released drill cuttings mainly consisted of smothering of foraminiferal fauna. Smothering was only observed in station S8 (Well S-2012) and G10 (Well G-2000). We therefore conclude that the observed impact of drill cutting releases at the wells G-2000 and S-2012 was confined to 30m downstream from the wellhead. Traditionally monitoring studies around wells mainly focus on samples collected $>250 \mathrm{~m}$ from the wellhead (Renaud et al., 2008). These might thus not capture the real environmental impact of drill cuttings.

Changes in foraminiferal assemblages in the cores collected at the transect at well E-1992 could be attributed to natural environmental change. No negative impact on the foraminiferal fauna from the released drill cuttings was observed. This is somewhat surprising as the well was drilled in 1992, i.e. before the stricter regulations on the use of oil based drill cuttings (NPD, 2017). The lack of environmental impact is opposite to findings at well T-1987 (Fig.1) drilled in 1987, where surface sediments $<30 \mathrm{~m}$ from the well show highly elevated heavy metal concentrations (Junttila et al., 2018) and impacted foraminiferal assemblages (AagaardSørensen et al., in review; Berg, 2017). It should be noted that the amount of drill cuttings at well E-1992 corresponded to 688 tons, while amounts released at well T-1987 corresponded to 3353 tons (Junttila et al., 2018; NPD, 2017). Additionally Ba concentrations at well E-1992 are up to 40 times lower than in well T-1987. This suggests that the amount of drill cuttings released has an impact on the extent of environmental impact as well.

\subsection{Recovery and present day environmental impact}

Live, rose Bengal stained foraminifera(Fig. 2) observed in the top $5 \mathrm{~cm}$ of the cores reflect the present day environmental conditions along the transects. The dominant live taxa observed in the stations are comparable to taxa observed in non-impacted areas of Ingøydjupet and the surrounding southern part of the Barents Sea (Dijkstra et al., 2013; Saher et al., 2012). This indicates that the modern foraminiferal assemblage was not impacted (anymore) by the released drill cuttings at the time of sampling.

Exception is station S8 at well S-2012. Live fauna is absent in the upper $5 \mathrm{~cm}$ of core S8. This indicates that the fauna had not recovered 3 years after the release of drill cuttings. High 
concentrations of $\mathrm{Cu}$ might be an explanation for this (Junttila et al., 2018). High sand content (i.e. up to 91\%; Fig. 5e; Junttila et al., 2018) and large amounts of particles $>2 \mathrm{~mm}(0-10 \mathrm{~cm}$ and 17-20 cm core depth; Junttila et al., 2018) found in station S8 might also have created unfavourable conditions for foraminifera to re-establish. Visual inspection of the wellhead with an ROV during sample taking showed high amounts of cement around the well (Suppl. Fig. Ib).

For the fossil fauna, we observed an increase in abundance of species grouped in Association I in the top part of core G10 at well G-2000, coinciding with decreasing Ba concentrations. We therefore interpret the top $4 \mathrm{~cm}$ of core G10 to reflect a recovery layer that has been deposited after the initial release of drill cuttings at well G-2000. A recovery layer is supported by the densities of a live fauna corresponding to live faunal densities downstream (G30-G250). As core G10 was collected 15 years after release of drill cuttings, a recovery layer of $4 \mathrm{~cm}$ would imply a sedimentation rate of $2.6 \mathrm{~mm} / \mathrm{year}$. This is slightly above the (natural) range in sedimentation rates Junttila et al., (2014) calculated for the Ingøydjupet trough, i.e. between 1.0 and $2.4 \mathrm{~mm} /$ year. This either implies a wider range in natural variability of sedimentation rates in the area, or increased input of sediments towards the site of core G10, for example as a result of re-transportation of drill cuttings from the wellhead.

A recovery layer was also confirmed by visual inspection of the samples through a microscope. The bottom part of core G10 mainly consisted of foam like and green particles (Supplementary figure Ia). These foam like and green particles are only present in very low amounts in the top part of the core.

\section{Conclusions}

The main aim of this study is to identify the environmental impact of released drill cuttings around three wells in the SW Barents Sea. These wells were drilled in 1992 (Well E-1992), 2000 (Well G-2000) and 2012 (Well S-2012) during which different regulations on discharge of environmental hazardous substances were active (Fig.1a and b). Sediment cores $(20 \mathrm{~cm}$ long) are studied along transects down-stream (>5-250 m away) from the wellheads (Fig. 1c). Drill cutting influenced sediment layers are identified by elevated Ba concentrations (ca. >200 $\mathrm{mg} / \mathrm{kg}$ ), as barite $\left(\mathrm{BaSO}_{4}\right)$ is used as weighing agent during the drilling process. Drill cutting influenced sediment layers are found along the entire transect at each of the wells varying in thickness of $1 \mathrm{~cm}$ up to $>20 \mathrm{~cm}$. 
The main environmental impact of released drill cuttings on the foraminiferal fauna is smothering, obstructing bioturbation and resulting in low foraminiferal abundance (Fig. 4b and 5b; well G-2000 and S-2012). The released drill cuttings do overall not result in changes in foraminiferal species composition (Fig. 3d, 4d and 5d). In well G-2000, we however observe a different foraminiferal fauna within the drill cutting deposits (Fig. 4d). These species are interpreted to be part of an old fossil fauna, released together with the drill cuttings.

Our findings at well E-1992 suggest that not all drill cuttings released before stricter regulations set in place in 1993 have resulted in negative environmental impact. The relatively low amounts of drill cuttings released seem to limit the environmental impact.

Our findings at well G-2000 indicate that the seafloor environment around the well has recovered, at least partly, 15 years after the release of drill cuttings. At well S-2012, absence of live fauna implies that no recovery of foraminiferal assemblage has occurred, 3 years after the release of drill cuttings.

Overall, it can be concluded that the effect of the released drill cuttings at all wells is confined to $<30 \mathrm{~m}$ from the wellhead. Traditional monitoring studies around wells mainly focus on samples collected $>250 \mathrm{~m}$ from the wellhead (Renaud et al., 2008), and might thus not capture the real environmental impact of drill cuttings. Increasing Ba concentrations towards present are observed in the wells at stations $\geq 30 \mathrm{~m}$ away from the wellhead. This indicates that $\mathrm{Ba}$ rich sediments are still being re-transported 3,15 and 23 years after the initial releases, yet with no influence on the foraminiferal assemblages.

\section{Acknowledgments}

This study is part of the Barents Sea Drill Cuttings Research Initiative (BARCUT) - project (WP 3) funded by ENI Norway. RDA Troms County is acknowledged for additional support. We would also like to thank the captain and crew of supply vessel AHTS Njord Viking and the ROV crew (Oceaneering), in addition to our colleagues in the BARCUT project. We would like to thank ENI Norway for providing ship time for sediment core collection. We thank the anonymous reviewer for constructive feedback on the manuscript. 


\section{References}

Aagaard-Sørensen, S., Berg, J., Junttila, J., Dijkstra, N., Landfald, B., in review. Lingering effect from petroleum exploration related pollution on benthic foraminiferal fauna compositions in the Ingøydjupet, SW Barents Sea. Polar Research.

Aagaard-Sørensen, S., Junttila, J., Dijkstra, N., 2018. Identifying past petroleum exploration related drill cutting releases and influences on the marine environment and benthic foraminiferal communities, Goliat Field, SW Barents Sea, Norway. Marine Pollution Bulletin 129, 592-608.

Altenbach, A.V., Pflaumann, U., Schiebel, R., 1999. Scaling percentages and distributional patterns of benthic foraminifera with flux rates or organic carbon. Journal of Foraminiferal Research 29, 173-185. Alve, E., 1995. Benthic foraminiferal response to estuarine pollution: a review. Journal of Foraminiferal Research 25, 190-203.

Alve, E., 1999. Colonization of new habitats by benthic foraminifera: a review. Earth-Science Reviews 46, 167-185.

Bakke, T., Källqvist, T., Ruus, A., Breedveld, G., Hylland, K., 2010. Development of sediment quality criteria in Norway. Journal Soils Sediments 10, 172-178.

Berg, J., 2017. Drill cutting release in Ingøydjupet, SW Barents Sea from a well drilled in 1987, and its impact on benthic foraminifera, Institute for Geosciences. UiT The Arctic University of Norway in Troms $\varnothing$, Troms $\varnothing$.

Breuer, E., Stevenson, A.G., Howe, J.A., Carroll, J., Shimmield, G.B., 2004. Drill cutting accumulations in the Northern and Central North Sea: a review of environmental interactions and chemical fate. Marine Pollution Bulletin 48, 12-25.

Cochrane, S.K.J., Ekehaug, S., Pettersen, R., Refit, E.C., Hansen, I.M., Aas, L.M.S., 2019. Detection of deposited drill cuttings on the sea floor - A comparison between underwater hyperspectral imagery and the human eye. Marine Pollution Bulletin 145, 67-80.

Corliss, B.H., 1985. Morphology and microhabitat preferences of benthic foraminifera from the northwest Atlantic Ocean. Marine Micropaleontology 17, 195-236.

Corliss, B.H., Van Weering, T.C.E., 1993. Living (stained) benthic foraminifera within surficial sediments of the Skagerrak. Marine Geology 111, 323-335.

Davies, J.M., Addy, J.M., Blackman, R.A., Blanchard, J.R., Ferbrache, J.E., Moore, D.C., Somerville, H.J., Whitehead, A., Wilkinson, T., 1984. Environmental effects of the use of oil-based drilling muds in the North Sea. Marine Pollution Bulletin 15, 363-370.

de Stigter, H.C., Jorissen, F., Van der Zwaan, G.J., 1998. Bathymetric distribution and microhabitat partitioning of live (Rose Bengal stained) benthic foraminifera along a shelf to deep sea transect in the southern Adriatic Sea. Journal of Foraminiferal Research 28, 40-65.

de Stigter, H.C., van der Zwaan, G.J., Langone, L., 1999. Differential rates of benthic foraminiferal test production in surface and subsurface sediment habitats in the southern Adriatic Sea. Palaeogeography, Palaeoclimatology, Palaeoecology 149, 67-88.

Dijkstra, N., Junttila, J., Aagaard-Sørensen, S., 2017a. Environmental baselines and reconstruction of Atlantic Water inflow in Bjørnøyrenna, SW Barents Sea, since 1800 CE. Marine Environmental Research 132, 117-131.

Dijkstra, N., Junttila, J., Carroll, J., Hald, M., Elvebakk, G., Godtliebsen, F., 2013. Living benthic foraminiferal assemblages and their relationship to grain size and element concentrations in surface sediments of the Ingøydjupet-Troms $\varnothing$ flaket region, southwestern Barents Sea. Marine Environmental Research 92.

Dijkstra, N., Junttila, J., Husum, K., Carroll, J., Hald, M., 2015. Natural variability of benthic foraminiferal assemblages and metal concentrations during the last $150 \mathrm{yrs}$ in the Ingøydjupet trough, SW Barents Sea. Marine Micropaleontology 121, 16-31.

Dijkstra, N., Junttila, J., Skirbekk, K., Carroll, J., Husum, K., Hald, M., 2017b. Benthic foraminifera as bio-indicators of chemical and physical stressors in Hammerfest harbor (Northern Norway). Marine Pollution Bulletin 114, 384-396. 
Dolven, J.K., Alve, E., Rygg, B., Magnusson, J., 2013. Defining past ecological status and in situ reference conditions using benthic foraminifera: A case study from the Oslofjord, Norway. Ecological Indicators 29, 219-233.

Ellis, B.E., Messina, A.R., 1940-1978. Catalogue of Foraminifera American Museum of Natural History, New York.

Fishbein, E., Patterson, R.T., 1993. Error-weighed maximum likelihood (EWML): a new statistically based method to cluster quantitative micropaleontological data. Journal of Paleontology 67, 475485.

Forcino, F.L., 2012. Multivariate assessment of the required sample size for community paleoecological research. Palaeogeography, Palaeoclimatology, Palaeoecology 315-316, 134-141.

Forcino, F.L., Leighton, L.R., Twerdy, P., Cahill, J.F., 2015. Reexamining Sample Size Requirements for Multivariate, Abundance-Based Community Research: When Resources are Limited, the Research Does Not Have to Be. PLoS One 10, 1-18.

Gautier, D.L., Bird, K.J., Charpentier, R.R., Grantz, A., Houseknecht, D.W., Klett, T.R., Moore, T.E., Pitman, J.K., Schenk, C.J., Schuenemeyer, J.H., Sørensen, K., Tennyson, M.E., Valin, Z.C., Wandrey, C.J., 2009. Assessment of Undiscovered Oil and Gas in the Arctic. Science 324, 1175-1179.

Gooday, A.J., Lambshead, P.J.D., 1989. Influence of seasonally deposited phytodetritus on benthic foraminiferal populations in the bathyal northeast Atlantic: the species response. Marine Ecology Progress Series 58, 53-67.

Hald, M., Korsun, S., 1997. Distribution of modern benthic foraminifera from fjords of Svalbard, European Arctic. Journal of Foraminiferal Research 27 27, 101-122.

Hald, M., Steinsund, P.I., 1992. Distribution of surface sediment benthic foraminifera in the southwestern Barents Sea. Journal of Foraminiferal Research 22, 347-362.

Hald, M., Steinsund, P.I., 1996. Benthic foraminifera and carbonate dissolution in surface sediments of the Barents-and Kara Seas, in: Stein, R., Ivanov, G.I., Levitan, M.A., Fahl, K. (Eds.), Surface sediment composition and sedimentary processes in the central Arctic Ocean and along the Eurasian Continental Margin pp. 285-307.

Hammer, Ø., Harper, D.A.T., Ryan, P.D., 2001. PAST: Paleontological Statistics Software Package for Education and Data Analysis. Palaeontologia Electronica 4, 1-9.

Harloff, J., Mackensen, A., 1997. Recent benthic foraminiferal associations and ecology of the Scotia Sea and Argentine Basin. Marine Micropaleontology 31, 1-29.

Hess, S., Alve, E., Trannum, H.C., Norlin, K., 2013. Benthic foraminiferal responses to water-based drill cuttings and natural sediment burial: Results from a mesocosm experiment. Marine Micropaleontology 101, 1-9.

Ingvaldsen, R., Asplin, L., Loeng, H., 2004. The seasonal cycle in the Atlantic transport to the Barents Sea during the years 1977-2001. Continental Shelf Research 24, 1015-1032.

Jennings, A.E., Weiner, N.J., Helgadottir, G., Andrews, J.T., 2004. Modern foraminiferal faunas of the southwestern to northern Iceland Shelf; oceanographic and environmental controls. Journal of Foraminiferal Research 34, 180-207.

Jensen, H.K.B., Boitsov, S., Finne T. E., Klungsøyr, J., Knies, J., 2009. Physical and chemical traces of anthropogenic influence at the seabed and in the sediments in Ingøydjupet, Southern Barents Sea. Norwegian Journal of Geology 89, 101-108.

Jorissen, F.J., Bicchi, E., Duchemin, G., Durrieu, J., Galgani, F., Cazes, L., Gaultier, M., Camps, R., 2009. Impact of oil-based drill mud disposal on benthic foraminiferal assemblages on the continental margin off Angola. Deep-Sea Research II 56, 2270-2291.

Junttila, J., Carroll, J., Husum, K., Dijkstra, N., 2014. Sediment transport and deposition in Ingøydjupet, SW Barents Sea. Continental Shelf Research 76, 53-63.

Junttila, J., Dijkstra, N., Aagaard-Sørensen, S., 2018. Spreading of drill cuttings and sediment recovery of three exploration wells of different ages, SW Barents Sea, Norway. Marine Pollution Bulletin 135, 224-238.

Knol, M., 2011. The uncertainties of precaution: Zero discharges in the Barents Sea. Marine Policy 35, 399-404. 
Korsun, S., Hald, M., 1998. Modern Benthic Foraminifera off Novaya Zemlya Tidewater Glaciers, Russian Arctic. Arctic and Alpine Research 30, 61-77.

Lamb, H.H., 1977. Climate, Present, Past and Future, Climate History and the Future. Methuen \& Co Ltd, London, p. 835.

Linke, P., Lutze, G.F., 1993. Microhabitat preferances of benthic foraminifera - a static concept or a dynamic adaptation to optimize food acquisition? Marine Micropaleontology 20, 215-234.

Loeblich, A.R., Tappan, H., 1987. Foraminiferal genera and their classification. Van Nostrand Reinhold Co, New York.

Loeng, H., 1991. Features of the physical oceanographic conditions of the Barents Sea. Polar Research 10, 5-18.

Lutze, G.F., Altenbach, A., 1991. Technik und Signifikanz der Lebendfarbung benthischer Foraminiferen mit Bengalrot. Geologisches Jahrbuch 128, 251-265.

Mackensen, A., Grobe, H., Kuhn, G., Fütterer, D.K., 1990. Benthic foraminiferal assemblages from the eastern Weddell Sea between 68 and 73 S: distribution, ecology and fossilization potential. Marine Micropaleontoly 16, 241-283.

Mackensen, A., Hald, M., 1988. Cassidulina teretis Tappan and C.laevigeta d'Orbigny; their modern and late Quaternary distribution in northern seas. Journal of Foraminiferal Research 18, 16-24.

Mackensen, A., Sejrup, H.P., Jansen, E., 1985. The distribution of living benthic foraminifera on the continental slope and rise of southwest Norway. Marine Micropaleontology 9, 275-306.

Mannvik, H.P., Wasbotten, I.H., Cochrane, S., 2011. Miljøundersøkelse i Region IX og X Barentshavet 2010, APN-report 5000-03. Akvaplan niva, Troms $\emptyset$, p. 37.

Mees, J., Boxshall, G.A., Costello, M.J., al, e., 2015. World Register of Marine Species (WoRMS). WoRMS Editorial Board.

MinistryofPetroleumandEnergy, 2004. White Paper No.38 (2003-2004) : om petroleumsvirksomheten, Oslo.

MinistryoftheEnvironment, 1997. White Paper No.58 (1996-1997) : environmental policy for a sustainable development -joint efforts for the future, Oslo.

MinistryoftheEnvironment, 2011. White Paper 10 (2010-2011): First update of the Integrated Management Plan for the Marine Environment of the Barents Sea-Lofoten Area, Oslo.

Mojtahid, M., Jorissen, F., Durrieu, J., Galgani, F., Howa, H., Redois, F., Camps, R., 2006. Benthic foraminifera as bio-indicators of drill cutting disposal in tropical east Atlantic outer shelf environments. Marine Micropaleontology 61, 58-75.

Murray, J., 2006. Ecology and applications of benthic foraminifera. Cambridge University Press, New York.

Neff, J.M., 2005. Composition, environmental fates, and biological effect of water based drilling muds and cuttings discharged to the marine environment: a synthesis and annotated bibliography, Report Prepared for the Petroleum Environmental Research Forum (PERF) and American Petroleum Institute, Battelle, Duxbury, MA, p. 73.

NPD, 2017. Norwegian Petroleum Directorate Factpages, Stavanger.

Nyholm, K.G., 1961. Morphogenesis and biology of the foraminifer Cibicides lobatulus. Zoologiska Bidrag Från Uppsala 33, 157-197.

Polovodova Asteman, I., Hnaslik, D., Nordberg, K., 2015. An almost completed pollution-recovery cycle reflected by sediment geochemistry and benthic foraminiferal assemblages in a SwedishNorwegian Skagerrak fjord. Marine Pollution Bulletin 95, 126-140.

Polyak, L., Solheim, A., 1994. Late- and postglacial environments in the northern Barents Sea, west of Franz Josef land. Polar Research 13, 197-207.

Renaud, P.E., Jensen, T., Wassbotten, I., Mannvik, H.P., Botnen, H., 2008. Offshore sediment monitoring on the Norwegian shelf - A regional approach 1996-2006. Akvaplan-niva, Troms $\varnothing$, p. 95.

Saher, M., Klitgaard-Kristensen, D., Hald, M., Pavlova, O., Lindal-Jørgensen, L., 2012. Changes in distribution of calcareous benthic foraminifera in the central Barents Sea between the periods 19651992 and 2005-2006. Global and Planetary Change 98-99, 81-96. 
Schafer, C.T., Collins, E.S., Smith, J.N., 1991. Relationship of Foraminifera and thecamoebian distributions to sediments contaminated by pulp mill effluent: Saguenay Fiord, Quebec, Canada. Marine Micropaleontology 17, 255-283.

Schönfeld, J., Alve, E., Geslin, E., Jorissen, F., Korsun, S., Spezzaferri, S., members.of.the.FOBIMO.workgroup, 2012. The FOBIMO (FOraminiferal Blo-MOnitoring) initiative towards a standardised protocol for soft-bottom benthic foraminiferal monitoring studies. Marine Micropaleontology, 1-13.

Sejrup, H.P., Birks, H.J.B., Klitgaard Kristensen, D., Madsen, H., 2004. Benthonic foraminiferal distributions and quantitative transfer functions for the northwest European continental margin. Marine Micropaleontology 53, 197-226.

Smart, C.W., Gooday, A.J., 1997. Recent benthic foraminifera in the abyssal Northeast Atlantic Ocean; relation to phytodetrital inputs. Journal of Foraminiferal Research 27, 85-92.

Steinsund, P.I., 1994. Benthic foraminifera in surface sediments of the Barents and Kara Seas; Modern and late Quaternary applications. University of Troms $\varnothing$, Troms $\varnothing$, p. 111.

Sun, X., Corliss, B.H., Brown, C.W., Showers, W.J., 2006. The effect of primary productivity and seasonality on the distribution of deep-sea benthic foraminifera in the North Atlantic. Deep sea research part A: Oceanographic research papers 53, 28-47.

Taguchi, Y.-H., Oono, Y., 2005. Relational patterns of gene expression via non-metric multidimensional scaling analysis. Bioinformatics 21, 730-740.

Walton, W.R., 1952. Techniques for recognition of living foraminifera. Contribution from the Cushman Foundation of Foraminiferal Research 3, 56-60.

Ward, J.H., 1963. Hierarchical grouping to optimize an objective function. Journal of the American Statistical Association 48, 236-244.

Wilson, L.J., Hald, M., Godtliebsen, F., 2011. Foraminiferal faunal evidence of twentieth-century Barents Sea warming. The Holocene 21, 527-537.

Wollenburg, J.E., Mackensen, A., 1998. On the vertical distribution of living (rose bengal stained) benthic foraminifers in the Arctic Ocean. Journal of Foraminiferal Research 28.

$\mathrm{Xu}, \mathrm{R} ., 2$ 2000. Characterization: Light Scattering Methods. Kluwer Academic Press, Norwell, Massachusetts. 


\section{Tables}

\section{Table 1.}

Overview of analysed material

\begin{tabular}{|c|c|c|c|c|}
\hline $\begin{array}{c}\text { Location } \\
\text { (well name) }\end{array}$ & $\begin{array}{l}\text { Distance } \\
\text { well (m) }\end{array}$ & Core name & $\begin{array}{l}\text { Analysed } \\
\text { intervals }\end{array}$ & $\begin{array}{c}\text { Reference to core } \\
\text { in text }\end{array}$ \\
\hline \multirow{5}{*}{$\begin{array}{l}\text { Well E-1992 } \\
(7122 / 4-1)\end{array}$} & 250 & $250-3$ & \multirow{5}{*}{$\begin{array}{l}0-8 \mathrm{~cm} \text { core depth: } 1 \mathrm{~cm} \text { interval } \\
\text { Thereafter: } 10.5,13.5,16.5,19.5 \mathrm{~cm}\end{array}$} & $\mathrm{E} 250$ \\
\hline & 125 & $125-1$ & & E125 \\
\hline & 60 & $60-6$ & & E60 \\
\hline & 30 & $30-9$ & & E30 \\
\hline & 5 & $5-10$ & & E5 \\
\hline \multirow{5}{*}{$\begin{array}{l}\text { Well G-2000 } \\
(7122 / 7-1)\end{array}$} & 250 & $250-6$ & \multirow{4}{*}{$\begin{array}{c}0-6 \mathrm{~cm} \text { core depth: } 1 \mathrm{~cm} \text { interval } \\
\text { Thereafter: } 7.5,9.5,11.5,13.5,15.5,17.5 \\
19.5 \mathrm{~cm}\end{array}$} & G250 \\
\hline & 125 & $125-3$ & & G125 \\
\hline & 60 & $60-11$ & & G60 \\
\hline & 30 & $30-5$ & & G30 \\
\hline & 10 & $10-6$ & entire core $: 1 \mathrm{~cm}$ interval & G10 \\
\hline \multirow{5}{*}{$\begin{array}{l}\text { Well S-2012 } \\
(7220 / 10-1)\end{array}$} & 250 & $250-9$ & \multirow{2}{*}{$\begin{array}{c}0-6 \mathrm{~cm} \text { core depth: } 1 \mathrm{~cm} \text { interval } \\
\text { Thereafter: } 7.5,9.5,11.5,13.5,15.5,17.5 \\
19.5 \mathrm{~cm}\end{array}$} & $\mathrm{~S} 250$ \\
\hline & 125 & $125-3$ & & S125 \\
\hline & 60 & $60-8$ & $\begin{array}{c}\text { 0-14 cm core depth: } 1 \mathrm{~cm} \text { interval } \\
\text { Thereafter: } 15.5,17.5,19.5 \mathrm{~cm}\end{array}$ & S60 \\
\hline & 30 & $30-5$ & entire core $: 1 \mathrm{~cm}$ interval & $\mathrm{S} 30$ \\
\hline & 8 & $8-1$ & entire core : $1 \mathrm{~cm}$ interval & S8 \\
\hline
\end{tabular}


Table 2.

(A) Metal data of cores collected at well G-2000. See also Supplementary data B

(B) Environmental quality classes and their corresponding metal concentrations after Bakke et al., 2010.

\begin{tabular}{|c|c|c|c|c|c|c|c|c|}
\hline \multicolumn{9}{|c|}{ (A) Range (mg/kg) } \\
\hline Station & Cd & $\mathrm{Cr}$ & $\mathrm{Cu}$ & $\mathrm{Hg}$ & $\mathbf{P b}$ & Zn & $\mathbf{T i}$ & Ba \\
\hline G10 & $0,04-0,11$ & $23-44$ & $13-31$ & $0,02-0,11$ & $9-19$ & $19-45$ & $625-3690$ & $2810-8730$ \\
\hline G30 & $0,02-0,23$ & $26-61$ & $9-29$ & $0,01-0,03$ & $6-11$ & $34-71$ & $467-1330$ & $50-4800$ \\
\hline G60 & $0,04-0,22$ & $20-144$ & $7-13$ & $0,01-0,02$ & $5-9$ & $29-47$ & $413-757$ & $48-785$ \\
\hline G125 & $0,02-0,18$ & $21-34$ & $7-10$ & $0,01-0,02$ & $6-9$ & $30-49$ & $492-674$ & $50-636$ \\
\hline G250 & $0,02-0,08$ & $19-35$ & $6-15$ & $0,01-0,02$ & $5-9$ & $23-47$ & $378-693$ & $36-552$ \\
\hline \multicolumn{7}{|c|}{ (B) Env. classes (Bakke et al., 2010) } & & \\
\hline Class & Cd & $\mathrm{Cr}$ & $\mathbf{C u}$ & $\mathbf{H g}$ & $\mathbf{P b}$ & Zn & & \\
\hline I & $<0.25$ & $<70$ & $<35$ & $<0.15$ & $<30$ & $<150$ & & \\
\hline II & $0.25-2.6$ & $70-560$ & $35-51$ & $0.15-0.63$ & $30-83$ & $150-360$ & & \\
\hline III & $2.6-15$ & $560-5900$ & $51-55$ & $0.63-0.86$ & $83-100$ & $360-590$ & & \\
\hline IV & $15-140$ & $5900-59000$ & $55-220$ & $0.86-1,6$ & $100-720$ & $590-4500$ & & \\
\hline V & $>140$ & $>59000$ & $>220$ & $>1.6$ & $>720$ & $>4500$ & & \\
\hline
\end{tabular}


Table 3.

Summary of the most common benthic foraminiferal species with associated water mass and environmental interpretation

\begin{tabular}{|c|c|c|c|c|}
\hline Ass. & Interpretation & Species / taxa & $\begin{array}{l}\text { Environmental } \\
\text { preferences }\end{array}$ & Reference \\
\hline \multirow[t]{6}{*}{ I } & \multirow{2}{*}{$\begin{array}{l}\text { Organic rich } \\
\text { conditions } \\
\text { (Atlantic) }\end{array}$} & M. barleeanus & \multirow{2}{*}{$\begin{array}{l}\text { degraded } \\
\text { organic matter; } \\
\text { fine grained } \\
\text { sediments }\end{array}$} & \multirow{2}{*}{$\begin{array}{l}\text { (e.g. Dijkstra et al., 2013; Linke and } \\
\text { Lutze, 1993; Mackensen et al., 1985) }\end{array}$} \\
\hline & & P. bulloides & & \\
\hline & \multirow{2}{*}{$\begin{array}{l}\text { High energy } \\
\text { environment }\end{array}$} & T. angulosa & \multirow{2}{*}{$\begin{array}{l}\text { epifaunal in } \\
\text { sandy } \\
\text { sediments; } \\
\text { high energy } \\
\text { environment }\end{array}$} & \multirow[b]{2}{*}{$\begin{array}{l}\text { (e.g. Hald and Steinsund, 1996; } \\
\text { Mackensen et al., 1985; Nyholm, 1961; } \\
\text { Steinsund, 1994) }\end{array}$} \\
\hline & & C. lobatulus & & \\
\hline & \multirow{3}{*}{$\begin{array}{l}\text { Atlantic } \\
\text { conditions } \\
\text { (saline \& } \\
\text { warm) }\end{array}$} & C. laevigata & warm, saline & \multirow{2}{*}{$\begin{array}{l}\text { (e.g. Altenbach et al., 1999; Hald and } \\
\text { Steinsund, 1992; Jennings et al., 2004; } \\
\text { Mackensen and Hald, 1988; Saher et al., } \\
\text { 2012; Sejrup et al., 2004; Steinsund, } \\
\text { 1994) }\end{array}$} \\
\hline & & E. nipponica & $\begin{array}{l}\text { warm; pulsed } \\
\text { food supply }\end{array}$ & \\
\hline \multirow[t]{5}{*}{ II } & & C. neoteretis & chilled Atlantic & $\begin{array}{l}\text { (e.g. Gooday and Lambshead, 1989; } \\
\text { Jennings et al., 2004; Mackensen and } \\
\text { Hald, 1988) }\end{array}$ \\
\hline & \multirow[t]{4}{*}{$\begin{array}{c}\text { Arctic } \\
\text { conditions } \\
(\text { fresh \& cool) }\end{array}$} & N. labradorica & $\begin{array}{l}\text { cool, Arctic } \\
\text { Front } \\
\text { pulsed } \\
\text { phytodetritus }\end{array}$ & \multirow[t]{4}{*}{$\begin{array}{l}\text { (e.g. Hald and Korsun, 1997; Hald and } \\
\text { Steinsund, 1992; Korsun and Hald, } \\
\text { 1998; Polyak and Solheim, 1994; Sejrup } \\
\text { et al., 2004; Smart and Gooday, 1997; } \\
\text { Sun et al., 2006; Wilson et al., 2011) }\end{array}$} \\
\hline & & Islandiella spp. & cool & \\
\hline & & E. clavatum & $\begin{array}{l}\text { low salinity and } \\
\text { temperature; } \\
\text { opportunistic }\end{array}$ & \\
\hline & & C. reniforme & $\begin{array}{l}\text { cooled saline } \\
\text { water; } \\
\text { opportunistic }\end{array}$ & \\
\hline
\end{tabular}




\section{$\underline{\text { Figure captions }}$}

Fig. 1 - Study area. (A) Map of the study area in the SW Barents Sea. The arrows indicate the main water masses, i.e. Atlantic water (red), Coastal water (green) and Arctic water (black). (B) Bathymetric map showing the locations of studied exploration wells (red triangles) and locations of other fields in the area (white triangles). Yellow circles indicate previous foraminiferal studies around wells in the study area (Well T-1987; AagaardSørensen et al., in review, Berg et al., 2017, Junttila et al., 2018. Well G-2006; AagaardSørensen et al., 2018) (C) Sketch showing sampling stations along the sampling transect.

Fig. 2 - Live assemblage. (A) Density or total absolute abundances (\# specimens/gram dry sed. weight) of live assemblage (top $5 \mathrm{~cm}$ ) along sampling transects at well E-1992, G-2000 and S-2012, separated into total calcareous abundance (calc.; light grey) and total agglutinated abundance (aggl.; dark grey). (B) Dominance (black dot; left y-axis) and Fisher alpha diversity (cross; right y-axis) of the live assemblage along the sampling transects. (C) Relative abundance (black line with dot; left y-axis) and species absolute abundances (grey shading; right $y$-axis) of the most common species along the sampling transect.

Fig. 3 Well E-1992; Fig. 4 Well G-2000; Fig. 5 Well S-2012 - Dead assemblage. Graphs show down core distribution of each of the shown parameters along the sampling transects (cores taken 5/8/10m, 30m, 60m, 125m, 250m from well head) (A) Ba-concentrations $(\mathrm{mg} / \mathrm{kg})$. Drill cutting (DC) influenced layers are indicated by yellow shading (data and interpretation well E-1992 and S-2012 from Junttila et al., 2018). (B) Foraminiferal density or total absolute abundance (\# specimens/g dry sed. weight) of dead assemblage, separated into total calcareous abundance (calc.; light grey) and total agglutinated abundance (aggl.; dark grey) (C) Dominance (dot; upper x-axis) and Fisher alpha diversity (cross; lower x-axis) of the dead assemblage. Black dot indicates samples in which $>100$ specimens were identified; white dots samples in which $<100$ specimens were identified. (D) Relative abundance (black line with dot; upper $\mathrm{x}$-axis) and species absolute abundances (grey shading; lower $\mathrm{x}$-axis) of the most common species. Black dot indicates samples in which $>100$ specimens were identified; white dots samples in which $<100$ specimens were identified. (E) Clay (light grey), silt (dark grey), sand (black) and TOC content (red line) of the cores (data Well E-1992 and S-2012 from Junttila et al., 2018). 
Fig. 6 - Down core distribution foraminiferal groups. (A) R-mode clustering of the common foraminiferal species; (B) Down core distribution of the summed relative abundance of the species of the two associations found with the R-mode clustering for the cores along each sampling transect. Down core Ba concentrations $(\mathrm{mg} / \mathrm{kg})$ are shown with red. Drill cutting (DC) influenced layers indicated with yellow shading.

\section{Supplementary figures}

Suppl. Fig I. (A) Left: Picture through microscope of 0.1-1 mm fraction of sample from top of core G10 $(0-4 \mathrm{~cm})$ consisting mainly of natural sediments Right: Picture through microscope of 0.1-1 mm fraction of sample from lower part of core G10 $(4-20 \mathrm{~cm})$ consisting mainly of drill cuttings (foam-like yellowish and green particles). (B) Picture of wellhead of well S-2012 taken with ROV shows cement casing around wellhead. Fishes for scale.

Suppl. Fig. II Clusters. (A) Q-mode clustering of the core samples based on their relative abundance of species assigned to association I and II for each of the three wells; (B) Clustering of the samples based on non-metric multidimensional scaling. Dark grey shading highlights samples assigned by Q-mode clustering to group I, light grey shading highlights samples assigned to group II. Different symbols indicate samples from the different cores collected at each well (see legend on figure), with sample depth indicated next to it.

Suppl. Fig III Spreading model. Schematic overview of spreading of the drill cuttings at each of the wells. Red indicates drill cutting influenced sediments based on higher $\mathrm{Ba}$ concentrations. Brown indicates sediments interpreted to be "natural". Wells E-1992 and S2012 after Junttila et al., 2018. 
Fig.1
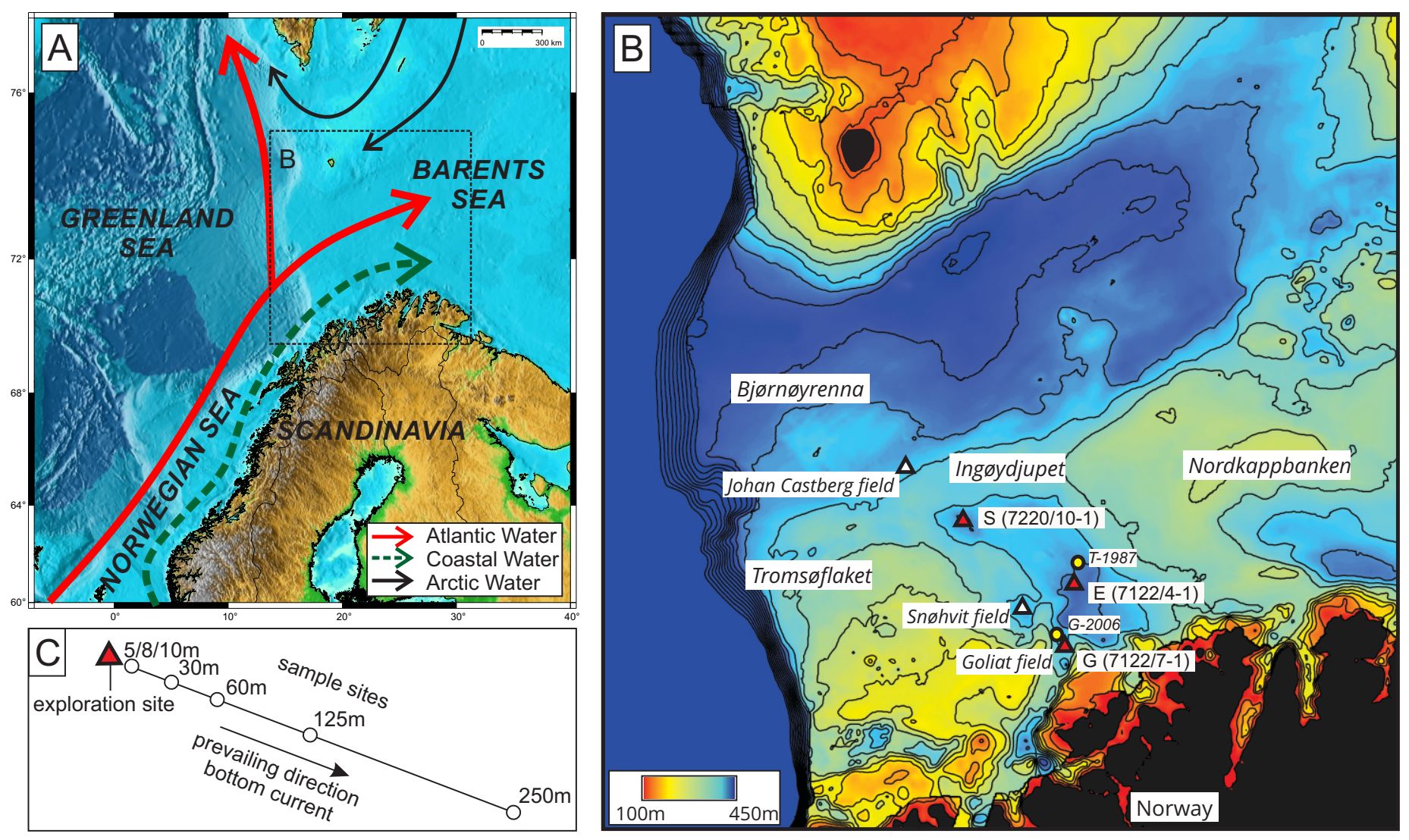
Fig.2

Well E- 1992 Well G- $2000 \quad$ Well S- 2012
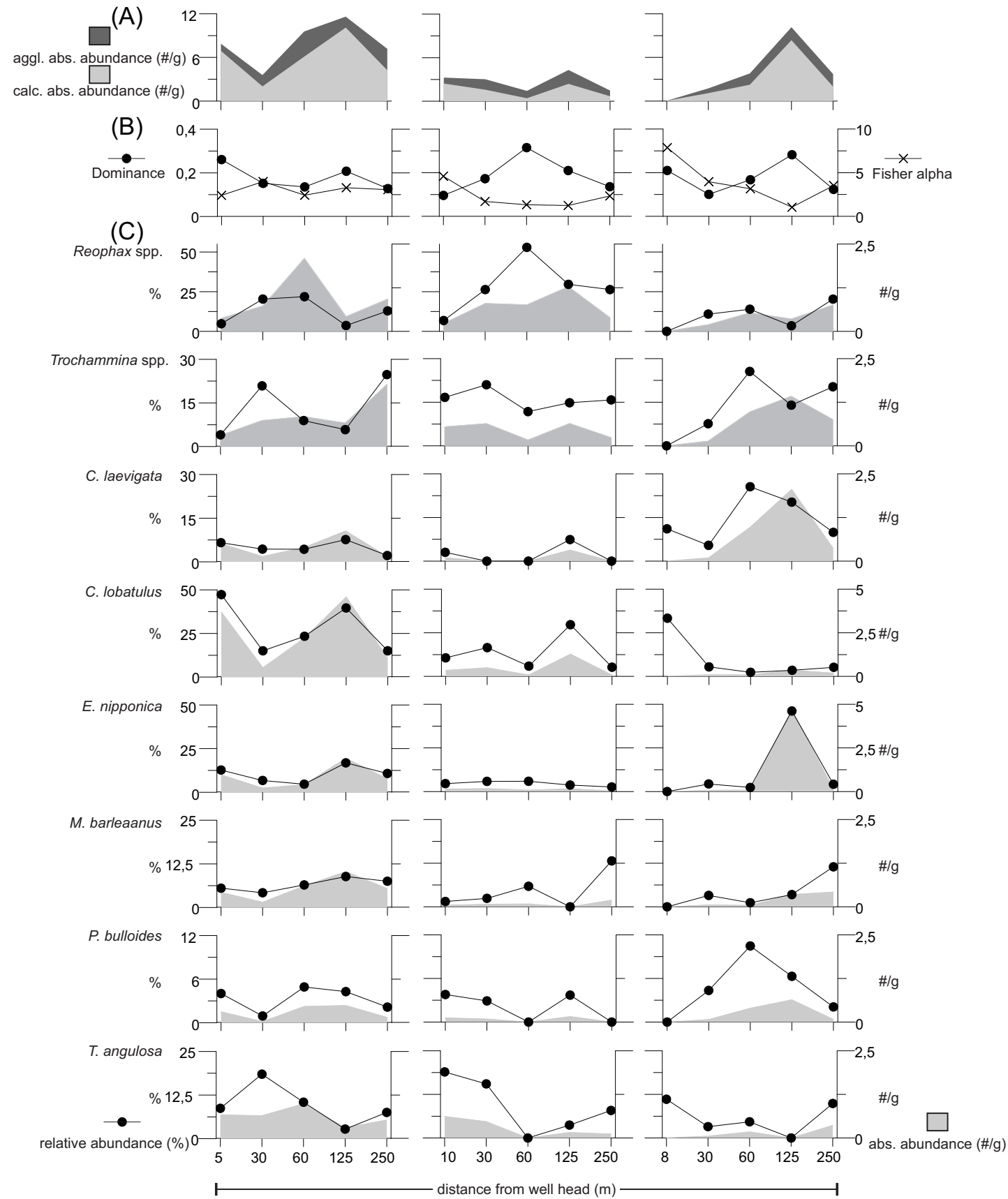


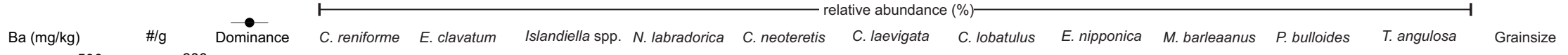

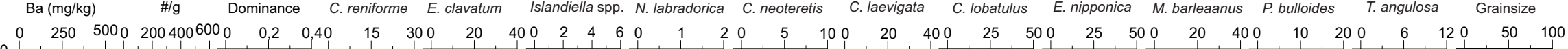
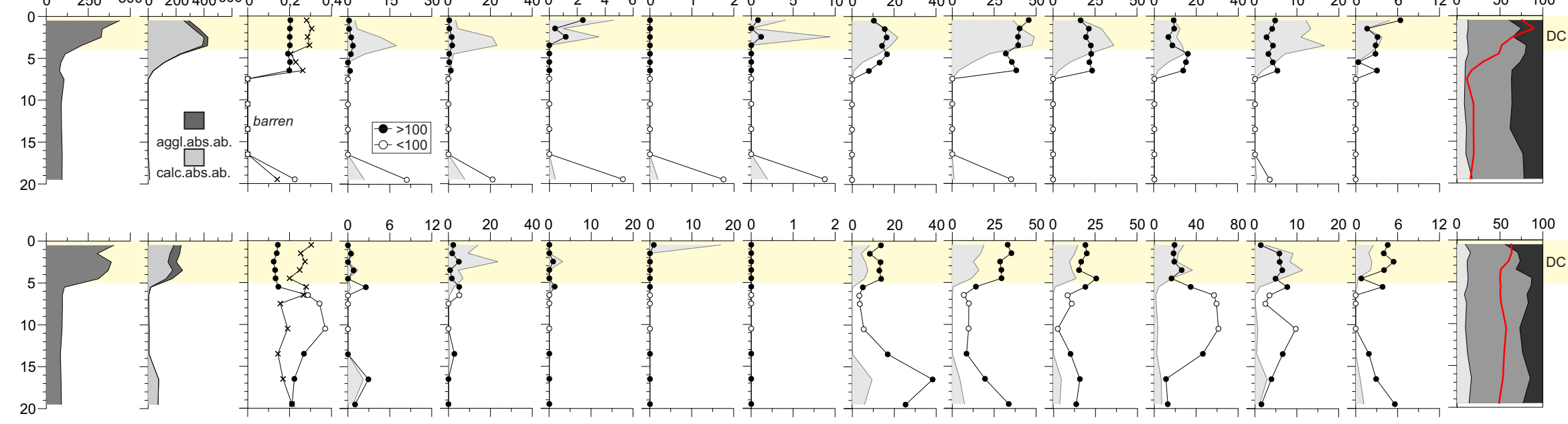

$30 \mathrm{~m}$

$60 \mathrm{~m}$
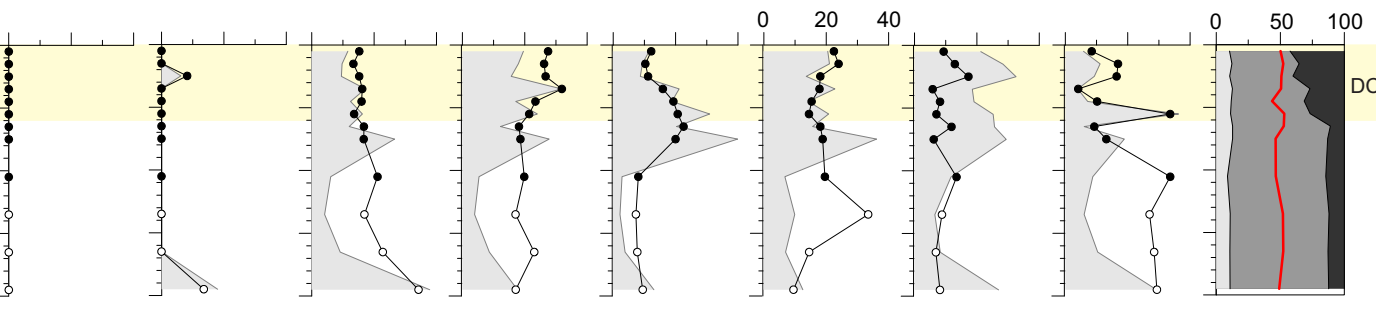

$125 \mathrm{~m}$
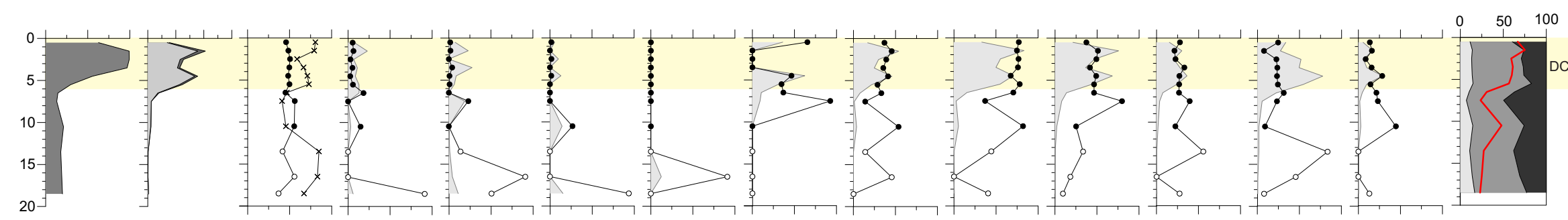

$250 \mathrm{~m}$
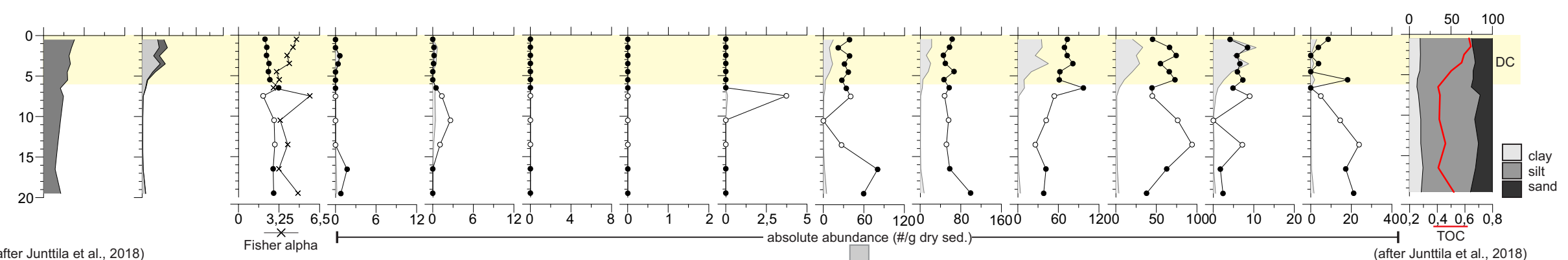

(after Junttila et al., 2018) 
Fig.4

Well G- 2000

(A) (B)

(C) (D)

$\mathrm{Ba}(\mathrm{mg} / \mathrm{kg})$

$10 \mathrm{~m}$

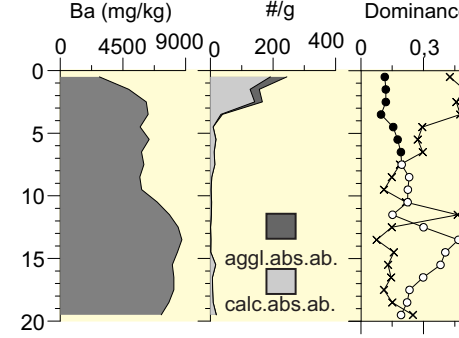

-
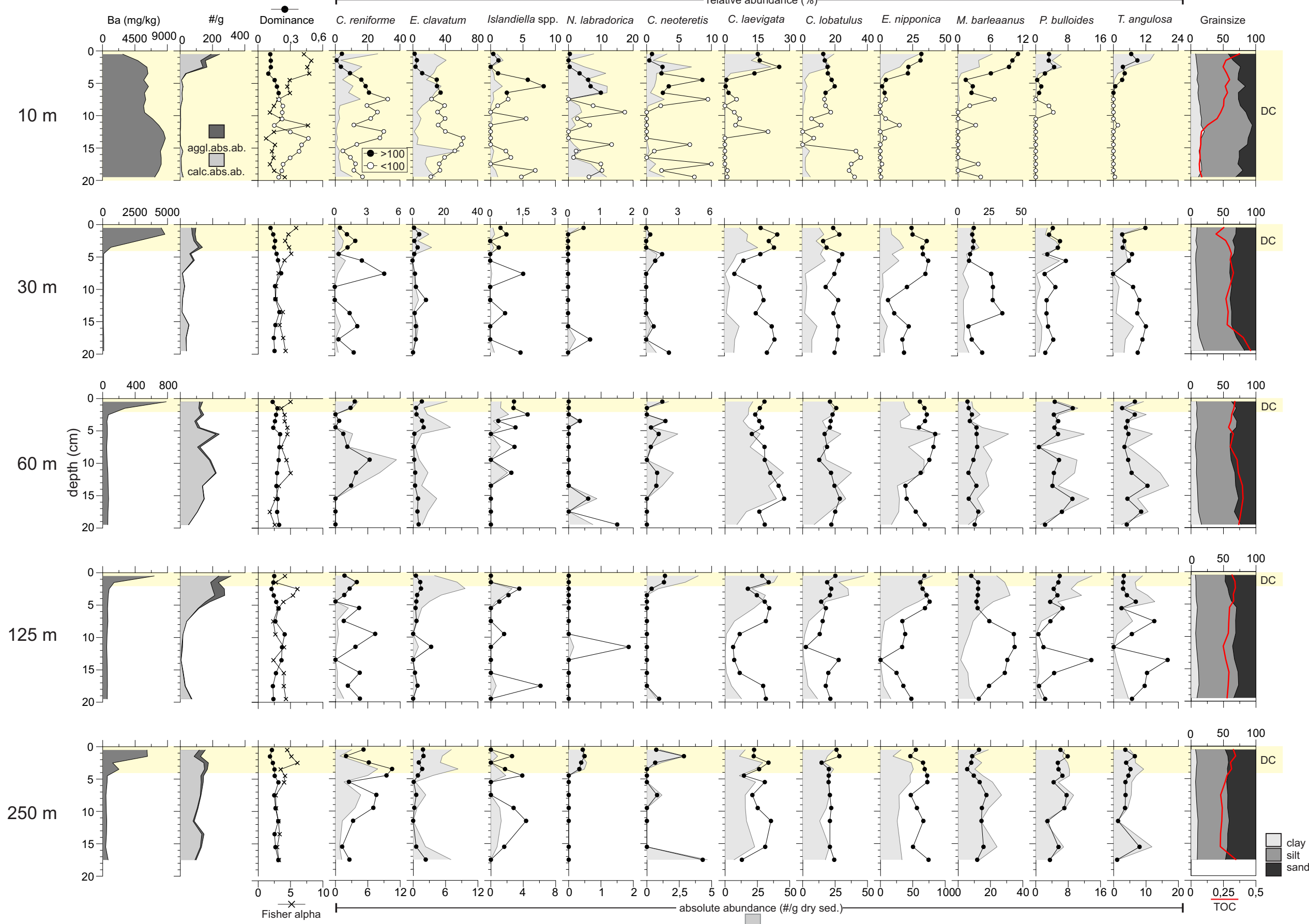


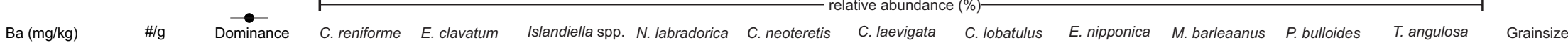

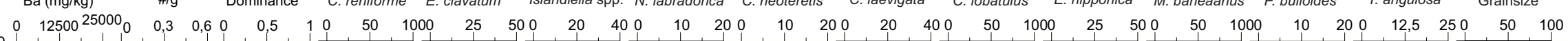

$8 \mathrm{~m}$
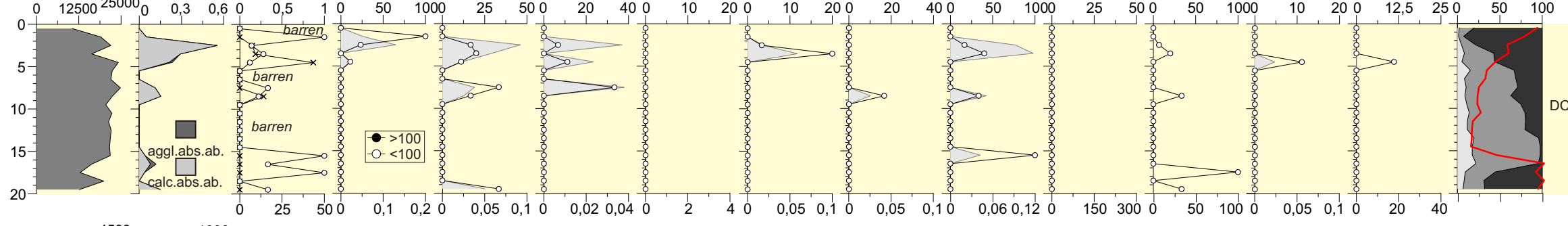

$30 \mathrm{~m}$
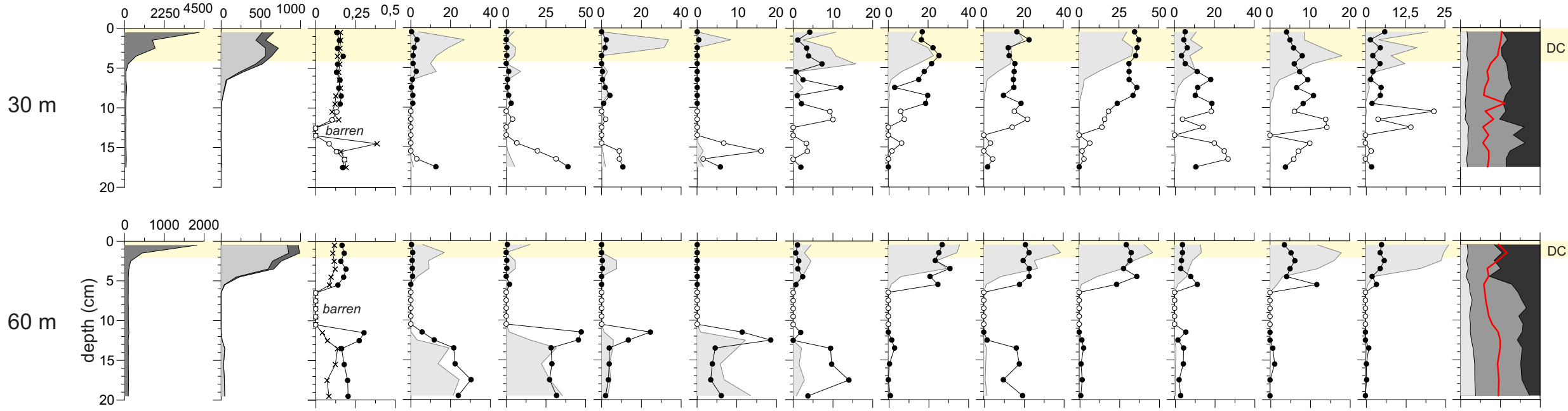

$125 \mathrm{~m}$
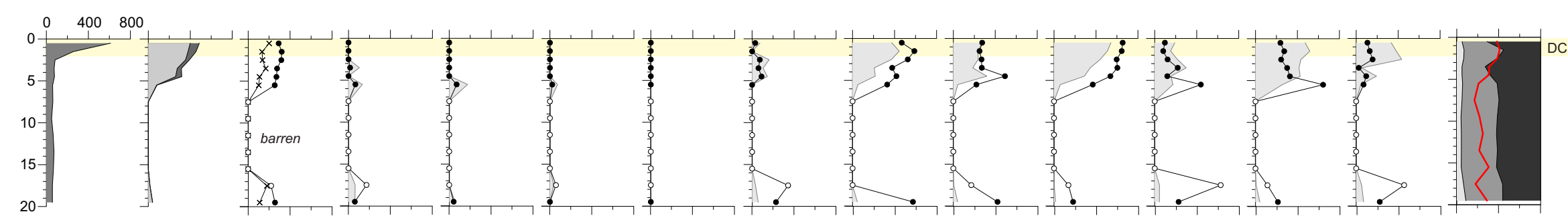

$250 \mathrm{~m}$
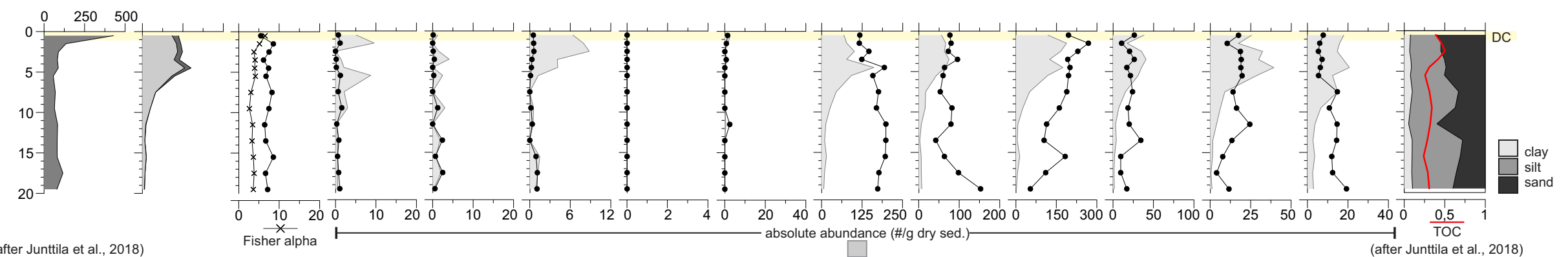
(A)

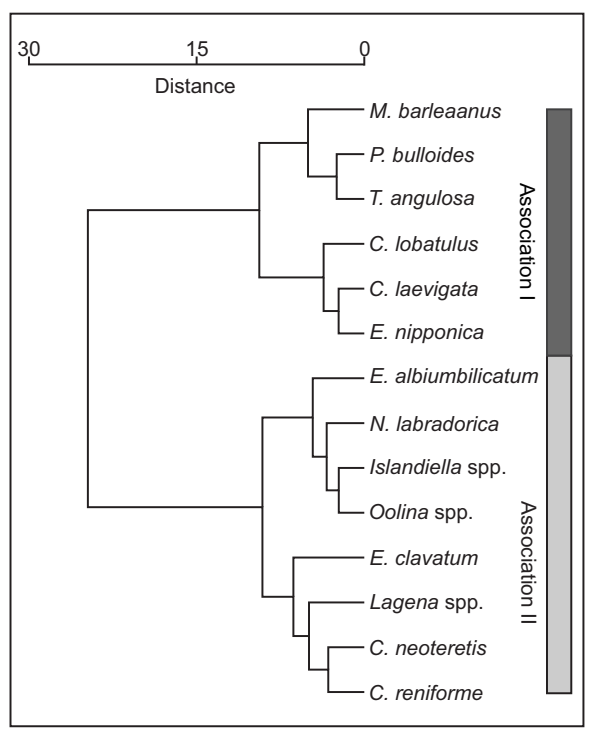

(B)
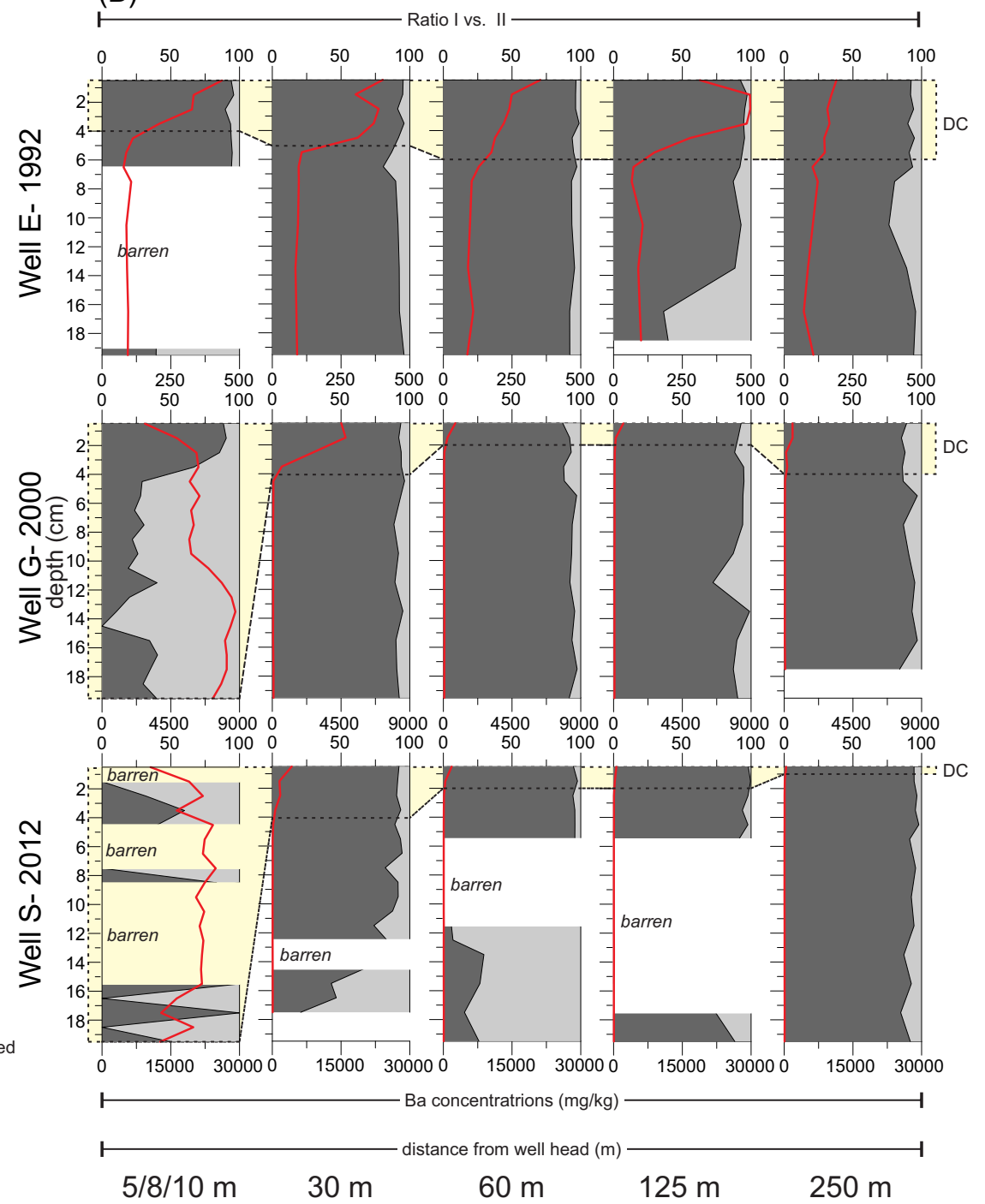


\section{Suppl. fig.I}

(A)
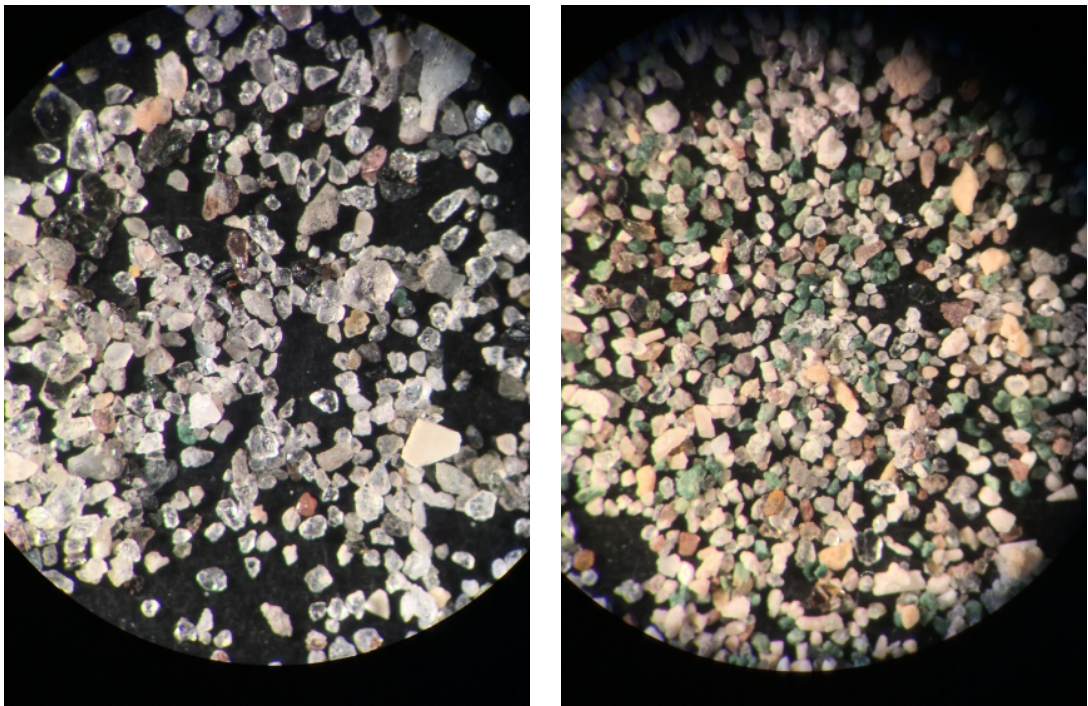

«natural»

«DC influenced»

(B)

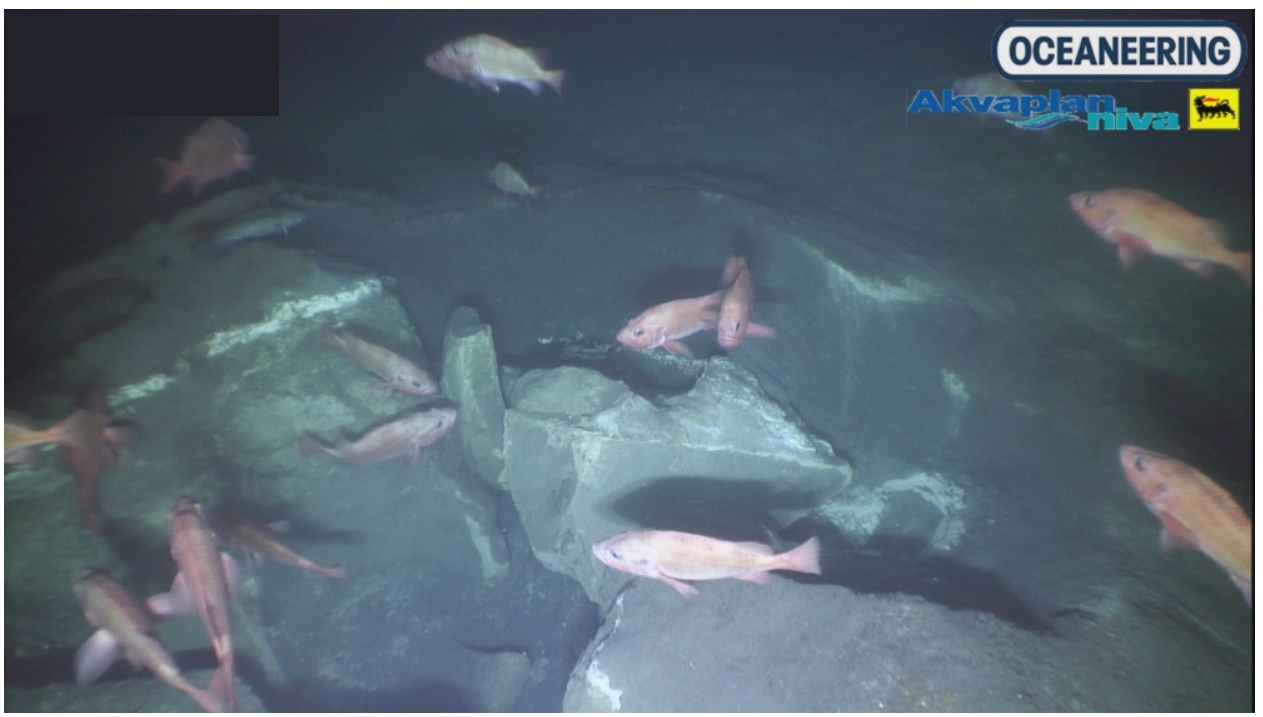




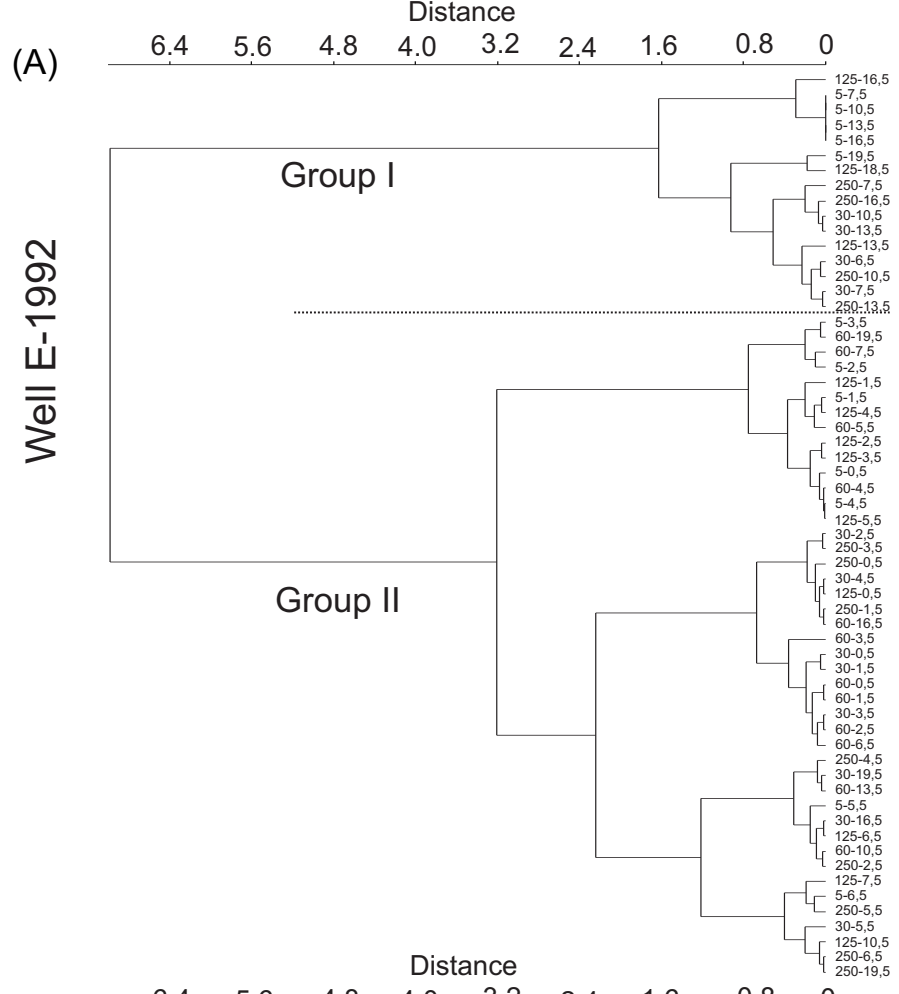

(B)

\section{Suppl. fig.II}

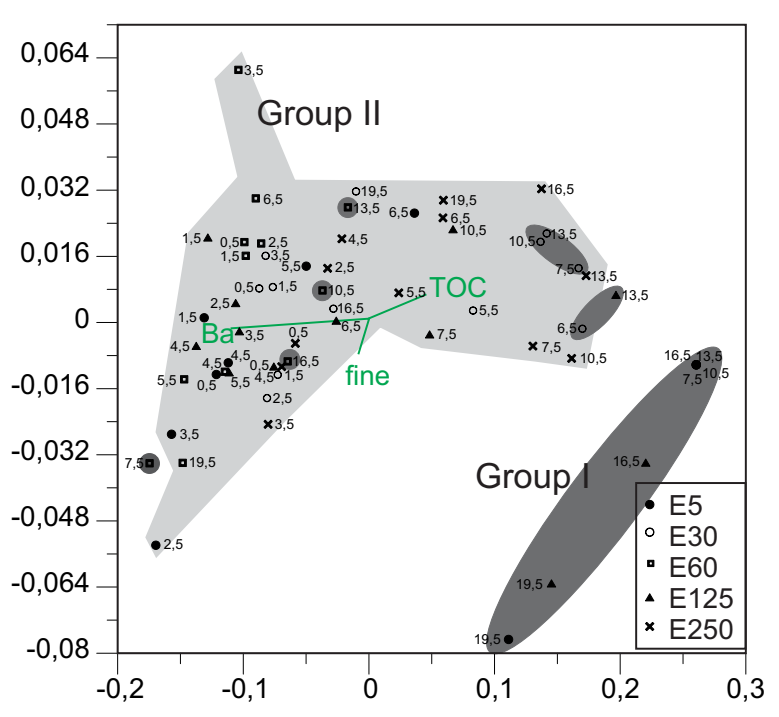

$\begin{array}{lllllllll}6.4 & 5.6 & 4.8 & 4.0 & 3.2 & 2.4 & 1.6 & 0.8 & 0\end{array}$
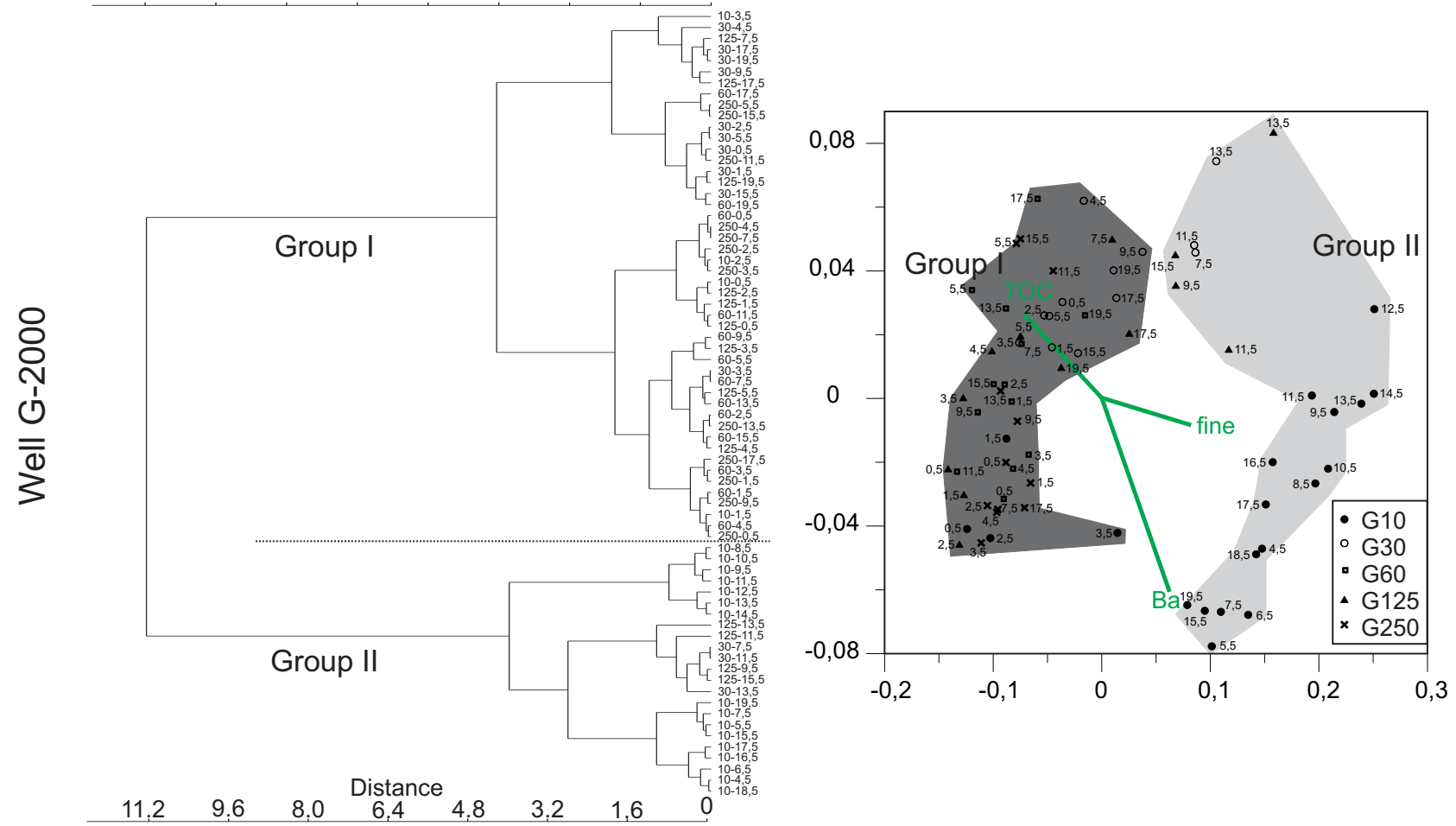

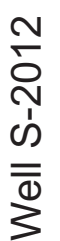
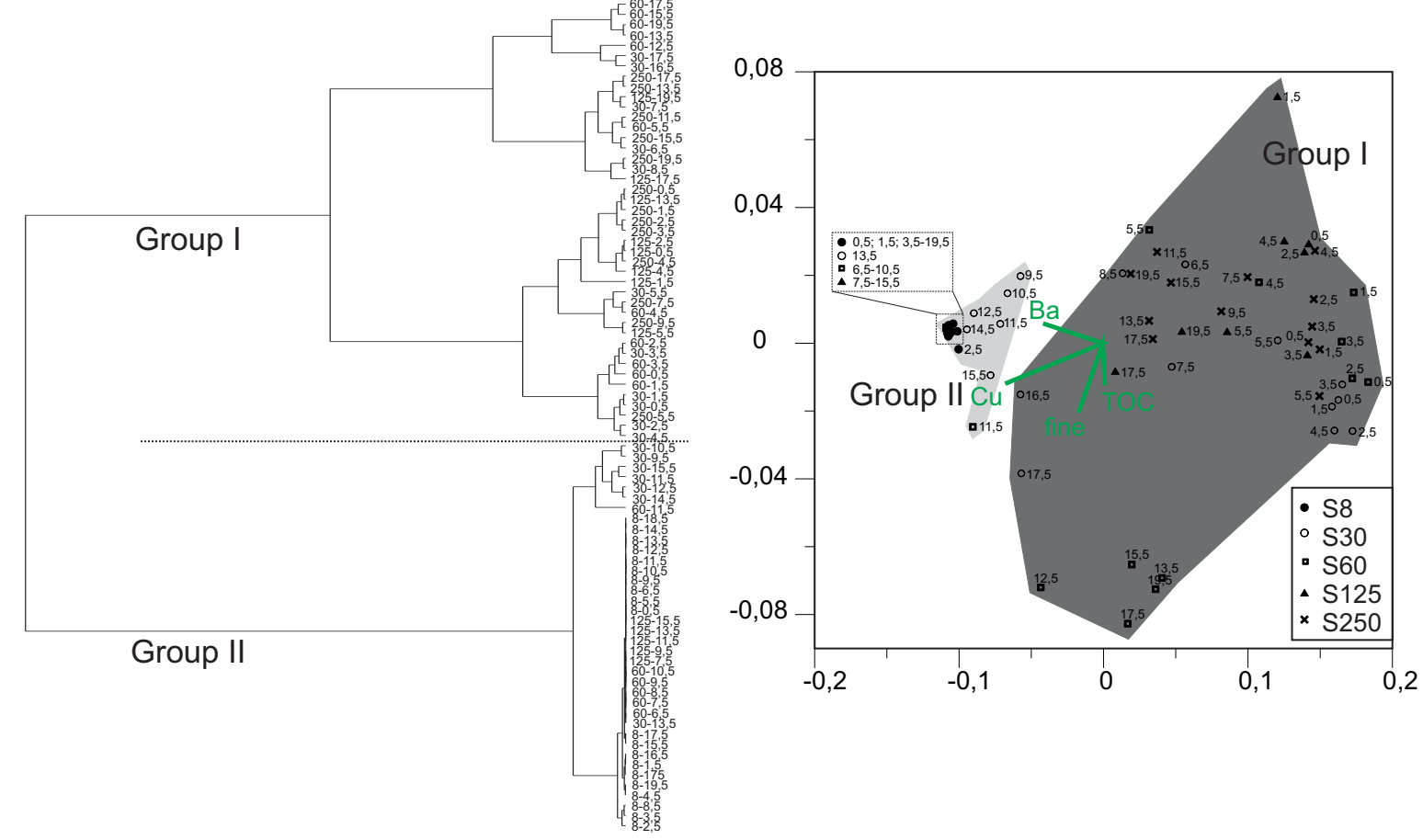


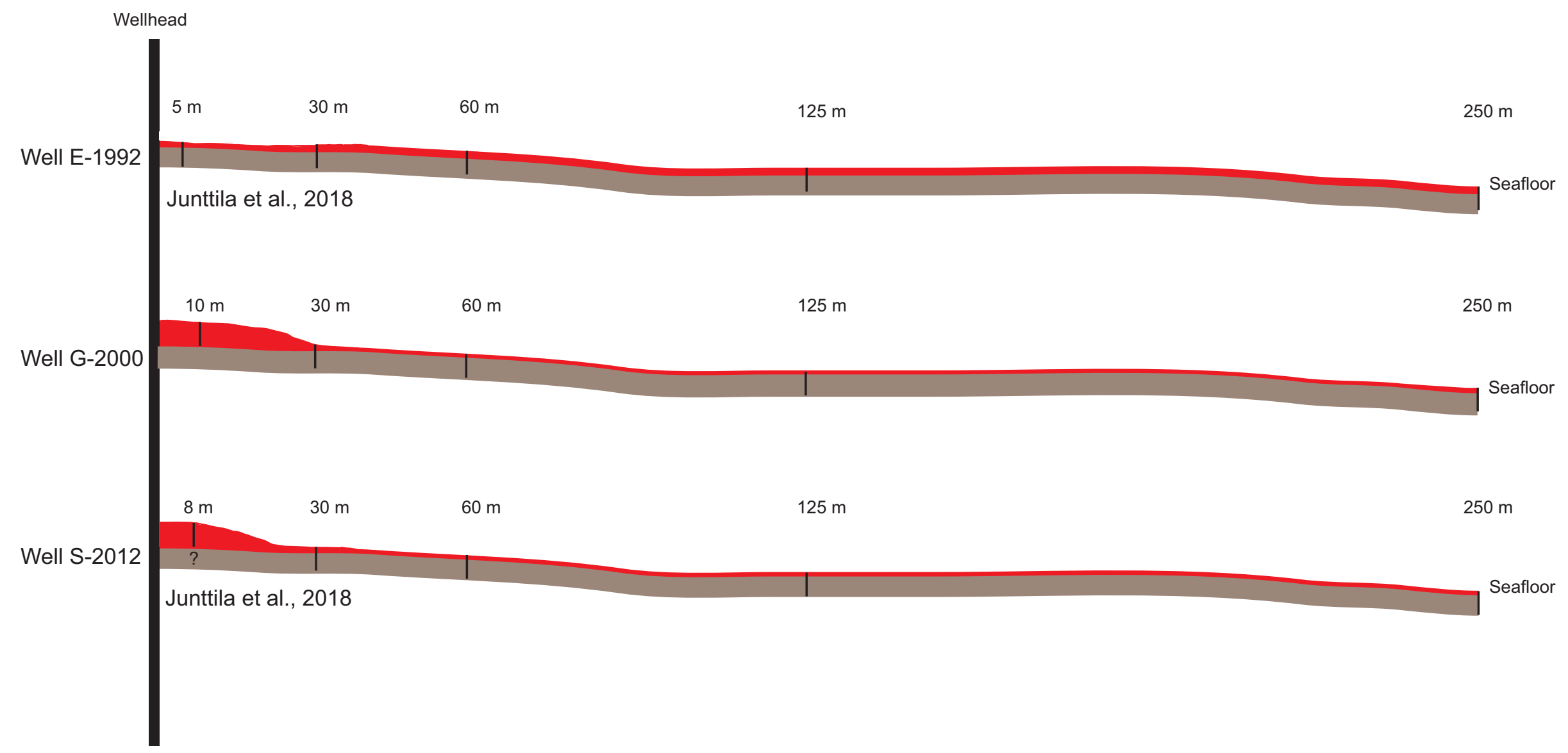

